\title{
Bank regulation, ownership and risk taking behavior in the MENA region: policy implications for banks in emerging economies
}

\author{
Miroslav Mateev ${ }^{1}$ D $\cdot$ Ahmad Sahyouni $^{2} \cdot$ Muhammad Usman Tariq $^{1}$
}

Received: 19 May 2021 / Accepted: 20 January 2022 / Published online: 7 February 2022

(c) The Author(s), under exclusive licence to Springer-Verlag GmbH Germany, part of Springer Nature 2022

\begin{abstract}
This paper investigates the impact of bank regulation and ownership on the risktaking behavior of financial institutions in the MENA region. We test the hypothesis that the effect of regulation on bank risk depends on the type of ownership structure. The public and private views of bank regulation are used to explain the relationship between regulatory measures and bank risk. We find that the official supervisory index exerts a positively associated with bank credit risk which is in line with 'private interest view' of bank regulation; however, private monitoring does have an opposite effect. The analysis of the regulatory measures impact on bank insolvency risk provides further support of the private interest view regarding the impact of market discipline. In addition to regulations, ownership structure (e.g., ownership concentration and foreign ownership) also plays a significant role in shaping the risk-taking behavior of banks in the MENA region. Our analysis reveals that the effect of banking regulations on risk-taking behavior strongly depends on the type of ownership structure prevailing in each banking system (Islamic and conventional). Our findings inform regulatory authorities concerned with improving the financial stability of banking sectors in the MENA countries and other emerging economies where Islamic and conventional banks co-exist, to carefully tailor banking reform initiatives depending on the type of the banking system as they may pursue different risk management strategies.
\end{abstract}

Keywords Bank regulation · Ownership · Credit and insolvency risk · Institution · Financial crisis

JEL Classification G21 · G28 · G30 • G38

Miroslav Mateev

m.mateev@adsm.ac.ae

1 Abu Dhabi School of Management, Abu Dhabi, UAE

2 Higher Institute for Administrative Development, Damascus University, Damascus, Syria 


\section{Introduction}

This study investigates the impact of bank regulation and ownership on banks' risktaking behavior in emerging economies, and more specifically, the Middle East and North Africa (MENA) region. As a result of the financial crisis in 2007-2008, the significance of the relationships among internal corporate governance mechanism (e.g., ownership), institutional governance mechanism (e.g., bank regulation), and bank risk-taking have become "more prominent to the policy makers to enhance banking sector stability and development" (Haque 2018, p. 3). Regulatory authorities in many countries have initiated banking reforms intended to improve corporate governance, capital adequacy, disclosure and transparency, and prudential regulations to reduce bank risk-taking behavior and enhance the financial stability of the banking systems. Accordingly, this paper examines the impact of regulation and ownership on banks' risk-taking behavior ${ }^{1}$ in the MENA region.

Two reasons make this research relevant. First, the financial stability issue has caused a great number of initiatives that focus on the need for better governance and tighter regulatory supervision (Mondher and Lamia 2016). As a result, regulatory authorities in many countries turned their attention to the development of new rules associated with stricter banking regulations and establishing a system of highquality governance. Capital requirements, supervisory power, and market-oriented disclosures are considered in this perspective as an important element of prudential regulations in light of the Basel Accords. Consequently, their impact on bank risktaking behavior became an important empirical question to investigate. Second, the recent empirical research shows that banks in the MENA region are continuously adjusting to the capital adequacy, liquidity, and risk management practices outlined in the Basel III framework. For example, previous studies report that the MENA countries, in general, and GCC countries, in particular, have made significant progress in implementing the Basel III standards by tightening capital and liquidity requirements, establishing "effective early warning systems and regular assessments of systemic risks as integral parts of macro-prudential policies" (Prasad et al. 2016, p. 22). The new Basel III requirements introduced in 2010 are expected to restrict banks' risk-taking and, thus, will affect banks' performance and stability (Alsharif et al. 2016).

There is a limited number of empirical studies investigating the effect of regulation on bank performance and risk-taking in the MENA region. The studies that focus on the bank performance (see, e.g., Haque and Brown 2017; Mateev and Bachvarov 2021) find a significant influence of ownership and regulation on the efficiency and profitability of banks in the MENA countries, whereas the exiting evidence on the effect of ownership structure and bank regulation on risk-taking

\footnotetext{
1 Risk-taking in banking has been long recognized in theoretical and empirical research and, most importantly, in the actual conduct of bank regulators. This relates to the behavior of banks to provide credit, that is, how banks are selecting borrowers, charging interest, and requiring collateral. The analysis of bank risk-taking considers factors such as bank charter value, ownership structure and regulatory environment (Chen et al. 2012).
} 
behavior is scarce. For example, Haque (2018) finds that the global financial crisis in 2008 and the subsequent policy initiatives do not moderate the influence of ownership and bank regulation on bank risk-taking in the MENA region. Moreover, the analysis reaches inconclusive evidence with respect to the effect of bank regulation (specifically, capital stringency and market discipline) on bank risktaking. A recent study by Li et al. (2021) investigates the effect of the COVID-19 pandemic on bank performance and risk related to the use of non-interest revenue sources. Their findings suggest that non-interest revenue sources are positively related to bank performance but inversely related to risk. These results are consistent with a beneficial portfolio diversification approach during the pandemic for banks expanding beyond traditional lending sources of income.

The existing empirical literature is not unanimous about the question of whether banks raise their risk levels in response to an increase in the regulatory pressure (e.g., increase in the minimum capital level of $8 \%$ ) or the other way round. This literature claims that regulation may affect banks' risk-taking behavior, but risky strategies of these banks, in turn, may induce the policy makers to impose stricter regulatory requirements (Ghosh 2017). We add value to this literature by investigating the influence of regulation and ownership on bank risk-taking using a large sample of banking institutions in 18 MENA countries, covering a period of 14 years (2005-2018). Specifically, we address the issue of whether the impact of regulation and ownership on bank risk-taking is different between conventional banks (CBs) and Islamic banks (IBs). The analysis of this issue becomes more important at least for two reasons: (i) IBs have become systemically relevant as they grow and increasingly interact with CBs that are systematically important, (ii) the lack of understanding of how the regulatory policy should be shaped to reflect the governing principles of Islamic banking better.

We contribute to the empirical literature in several ways. First, prior literature investigating the impact of regulation and ownership on bank risk-taking behavior argues that the increased bank supervision is likely to make monitoring and disciplinary mechanisms more effective. This in turn, reduces bank risk-taking (Barth et al. 2013), while activity restrictions increase bank risk, especially when the bank has a large owner (Laeven and Levine 2009). Since the evidence on the impact of regulatory reforms on banks' risk-taking behavior in the MENA region is scarce, we test the public and the private views of bank regulation for our sample of banks. We find that the official supervisory index is positively associated with bank credit risk, which is in line with the 'private interest view' of bank regulation; however, the private monitoring measure is negatively associated with bank risk, which supports the 'public interest view' hypothesis. Second, prior research on banking systems in the MENA region (see, e.g., Haque 2018) reports that the effect of regulation depends on the type of ownership structure of banks. We provide new evidence about the moderating role of ownership for the relationship between regulatory measures and bank risk-taking. Our results indicate a significant interaction effect between all the regulatory measures and the ownership concentration variable (except capital regulation). Therefore, we should expect that regulatory effects will be more pronounced for banks with a higher concentration of ownership. 
Finally, the question of whether the effect of regulation and ownership is different between Islamic and conventional banking systems has not been investigated so far. We are the first to discover that regulations and ownership effects on bank risk-taking are significantly different between the two banking systems. While in the sample of $\mathrm{CBs}$, the ownership structures that moderate the relationship between regulatory measures and credit risk is government shareholding and ownership concentration, in the sample of IBs, the interaction effect with ownership indicators is insignificant. This result should inform policy makers that stringent regulations will enforce CBs with concentrated ownership and high government presence to reduce their risk level. In opposite, for IBs, the effect of regulatory reforms will not depend on the type of ownership structure of a bank but rather on regulatory authority's behavior.

Our study differs from previous research on the MENA region in two ways. While previous studies (see e.g., Haque 2018) investigating the regulatory impact on bank risk-taking behavior in the MENA region finds that the global financial crisis in 2008 and the subsequent policy initiatives do not moderate the influence of ownership and bank regulation on bank risk-taking, we report a significant moderating effect for banks with concentrated ownership and high foreign presence. Second, prior research is silent about the differential impact of regulatory reforms on the IBs' risk behavior. We are the first to provide evidence that the ownership structure (e.g., government shareholding and ownership concentration) moderates the relationship between regulatory measures and risk-taking only in the sample of CBs while this effect is insignificant for IBs. Our results inform regulators and policy makers in the MENA (and other) regions where IBs and CBs co-exist, not to treat the two types of banks identically since the implementation of bank regulation reforms depends on the ownership structure prevailing in each banking system.

Our paper is organized as follows: Sect. 2 presents the literature review and formulates the hypotheses. Section 3 describes the data set and the research methodology. Section 4 contains the results of the empirical analysis and the interpretations. Section 5 includes a robustness check and alternative specifications. Finally, Sect. 6 details our conclusions.

\section{Theoretical framework and hypotheses}

\subsection{The impact of regulation on bank risk-taking behavior}

Both theoretical literature and empirical studies about the relationship between regulation and bank risk-taking provide conflicting evidence. According to Haque and Brown (2017), there is no underlying theoretical framework on bank regulation and consensus on what should be done to reform regulation in the MENA region. According to Barth et al. (2013), two opposite perspectives can explain these inconsistencies: the public and private interest views of bank regulation.

The first one, the 'public interest view,' suggests that governments aim to protect the interests of the public through regulating banking activities, which in turn increases bank efficiency and helps to mitigate the prospect of market failures. The second view, the 'private interest view', suggests that certain bank regulations 
are endorsed or even enforced to maximize the interests of a particular group of investors, leading to an increase in bank risk-taking. Accordingly, Andres and Vallelado (2008) argue that bank regulations decrease the effectiveness of other governance mechanisms in copying with corporate governance problems. This is the case when regulation imposes ownership restrictions, limits operations allowed to banking institutions, or reduces competition in the banking industry. The inconsistency between the two views lies in the fact that a country's regulations might give considerable flexibility to banks, but regulators might prevent banks from using that flexibility (Beltratti and Stulz 2012). Therefore, it is important to analyze the impact of different regulatory measures on bank risk-taking from the perspective of these two viewpoints.

In general, capital regulations tend to discipline the risk-taking behavior of banks. However, the theoretical literature that investigates the impact of regulatory measures on bank risk and performance reaches mixed views about the outcome of a higher capital requirement. According to the 'public interest view' of bank regulation, official capital adequacy regulations are believed to play a critical role in aligning the incentives of bank owners with depositors and other creditors, which results in more careful lending and better bank performance. However, this belief seems to ignore possible regulatory costs in higher entry barriers and greater rent extraction by governments that result from higher capital requirements. In opposite, the supporters of the 'private interest view' tend to oppose the reliance on stringent capital regulation unless it can be shown that the benefits exceed the costs, and there is a chance of finding an alternative solution to adverse incentive problems (Barth et al. 2013). These arguments lead one to suspect that more stringent capital requirements bring about an efficiency loss in banking.

In theory, activity restrictions are likely to affect bank performance and risk positively or negatively. According to the 'public interest view,' limiting a bank's activities, regulatory restrictions reduce moral hazard problems, discipline excessive risktaking behavior of banks by restricting banks from engaging in derivatives and other non-interest income-related activities, and thus reduce the financial activities may lead to the formation of extremely large and complex entities that are extraordinarily difficult to monitor and "too big to discipline" (Agoraki et al. 2011; Barth et al. 2013). In contrast, the 'private interest view' of bank regulation suggests that higher restrictions on bank activities tend to reduce the exploitation of economies of scope and scale in gathering and processing information about firms, building reputational capital, and providing various types of services to customers (Barth et al. 2013; Laeven and Levine 2009). Moreover, the supporters of the 'private interest view' argue that the restrictions can be structured so as to give discretion to the regulators and thus increase their bargaining power for rent-seeking (Djankov et al. 2002). These arguments seem to imply a positive association between activity restrictions and bank risk-taking.

Previous studies report that best-performing banks are usually coming from more strictly regulated countries, that is, from countries "with more powerful supervisors, more restrictions on what counts as capital, more restrictions on banking activities, and more private monitoring" (Beltratti and Stulz 2012, p.20). In line with this finding, the 'public interest view' suggests that powerful and independent 
bank supervisors/regulators have the incentive and expertise to enhance bank efficiency and reduce bank risk-taking through implementing effective monitoring and disciplinary mechanisms and enforcing better corporate governance standards (Beck et al. 2006; Barth et al. 2013). However, the 'private interest view' hypothesis suggests that powerful supervisors can influence banks to rent loans to maximize private benefits or political interests as they have little incentives to restrict bank risk-taking in the greater interest of the depositors and general public (Beck et al. 2006; Agoraki et al. 2011). Empirically, Maghyereh and Awartani (2014) find that the official supervisory index has a negative association with the likelihood of bank distress in the GCC region, whereas Haque (2018) reports a positive relationship between the official supervisory index and bank risk-taking, and this relationship is reinforced for banks with a higher concentration of ownership. Therefore, the effect of the power of the regulators is ambiguous.

Anginer and Demirgüç-Kunt (2014) argue that the banking system is more fragile in countries with weak supervision and private monitoring, generous deposit insurance and greater government ownership of banks, and public policies that restrict competition. Hence, increased market discipline and better monitoring are expected to reduce the negative effects of a concentrated banking market and enforce the prudent risk-taking behavior of banks. Accordingly, the 'public interest view' suggests that appropriate regulatory initiatives related to the disclosure of reliable, comprehensive, and consolidated information on bank activities and their risk management practices tend to reduce information asymmetry with disciplined measures coming from investors and other suppliers of funds, as opposed to regulators (Beck et al. 2006; Barth et al. 2013). In line with the 'private interest view,' most empirical studies (see, e.g., Barth et al. 2013; Pasiouras et al. 2009) find market-based disclosures and monitoring to positively affect bank efficiency. However, Bourgain et al. (2012) assert that financial disclosure increases the likelihood of a bank adopting sound risk management practices only in the presence of high financial openness. Thus, market-oriented disclosure practices are likely to restrain banks from excessive risk-taking.

\subsection{The impact of ownership structure on bank risk-taking}

Previous research emphasizes two types of ownership structures used to measure internal corporate governance. According to Haque (2018), these are the concentration of ownership as measured by the percentage of shareholding of the largest shareholder and the types of ownership that include government shareholding and foreign ownership.

Empirical literature finds that ownership concentration influences risk-taking behavior; however, the available empirical evidence on how ownership concentration affects risk-taking is largely inconclusive. For example, Laeven and Levine (2009) empirically estimate the link between bank risk-taking, the structure of ownership, and national bank regulations. They find that banks with more powerful owners tend to take the greater risk since owners with greater power and significant holding of cash flows have enough influence on bank managers to convince them to 
increase risk-taking. The reason is that through the increase of risk, managers generate a higher return. On the contrary, Iannotta et al. (2007) provide evidence that ownership concentration has a positive relationship with loan quality and a negative relationship with assets risk and the insolvency risk among the banks in the Far East and Europe. Using a cross-country study, Shehzad et al. (2010) find that ownership concentration significantly reduces banks' risk at low levels of shareholder protection and weak supervisory control. In line with the previous studies on the MENA region (see, e.g., Srairi 2013), we expect a negative association between ownership concentration and bank risk-taking.

According to Shleifer and Vishny (1997), government ownership of banks might be justified from the perspective of social welfare arguments and the need to address monopoly power and distributional concerns. The empirical evidence on the effect of government ownership is mixed. For example, Otchere (2005) argues that government ownership in the financial sector benefits countries with underdeveloped institutions, while Haw et al. (2010) find that government control is subject to greater agency conflicts in countries with weak legal and regulatory institutions. Likewise, government ownership brings inefficiency because of conflicts between social objectives and political interests, bureaucracy and corruption, and interest group politics. The research on government ownership and its effect on bank performance in the MENA region also finds mixed results. For example, Lassoued et al. (2016) find government ownership is positively associated with bank risk-taking, whereas Hammami and Boubaker (2015) report an opposite effect. Therefore, the effect of government ownership is ambiguous.

The impact of foreign ownership has also been investigated in the banking literature. It is well-known that foreign banks face 'liabilities of foreignness', which includes additional operating costs in overseas markets and difficulties in adopting the host country's legal norms and practices (Kobeissi and Sun 2010). These additional costs related to liabilities of foreignness can cause greater risk in overseas markets. However, the 'global advantage' hypothesis suggests that foreign banks might benefit from more advanced technologies, a highly skilled labor force, and better risk management practices in the host countries (Lensink et al. 2008; Haque 2018). This is likely to help foreign banks overcome the liabilities of foreignness in less competitive host countries and reduce the overall bank risk. Micco et al. (2007) shows that foreign banks often outperform domestic banks in terms of profitability, cost efficiency, and competitiveness in developing and emerging economies. According to Agoraki et al. (2011) and Lassoued et al. (2016) foreign ownership reduces bank risk-taking in emerging economies.

\subsection{Hypotheses of the study}

We draw our hypotheses in line with the 'public interest view' or 'private interest view' and the available empirical evidence. For example, since the MENA region shows significant progress in implementing Basel III capital requirements and 
related capital regulation, ${ }^{2}$ this is likely to impose a more disciplined approach in bank lending decisions, leading to improved bank efficiency. According to Barth et al. (2013), stringent capital regulation may help reduce bank risk, but at the expense of some efficiency loss. In line with the 'public interest view,' Maghyereh and Awartani (2014) find activity restrictions to have a negative effect on bank distress risks in the GCC region. Considering the limited scope of capital market activities of banks in the MENA countries, we expect activity restrictions to negatively affect bank risk-taking. Therefore, we test the following hypothesis:

Hypothesis 1. Capital regulation and activity restrictions are negatively associated with bank risk-taking.

In line with the 'public interest view' hypothesis, powerful and independent bank supervisors/regulators have the incentive and expertise to enhance bank efficiency and reduce bank risk-taking through implementing effective monitoring and disciplinary mechanisms. However, a study of banks in the MENA region by Haque (2018) finds that the official supervisory index employs a positive relationship with bank risk-taking, and this relationship is reinforced for banks with a higher concentration of ownership. On the other hand, given the recent changes in the bank regulations in the MENA countries related to the disclosure of off-balance sheet items and improved risk management practices, market-oriented disclosure policies and practices are likely to restrict bank risk-raking. Based on these findings, we test the following hypothesis:

Hypothesis 2. Official supervisory power is positively associated with bank risk-taking, whereas the private monitoring effect is negative.

Haw et al. (2010) argue that concentrated shareholding can cause more significant agency problems in the banking sector, leading to connected lending and relationship banking. Accordingly, they find that concentrated control exhibits greater return volatility and higher insolvency risks among listed commercial banks. However, Srairi (2013) finds an inverse association between ownership concentration and bank risk-taking in the MENA countries. Thus, the existing empirical evidence seems to be inconclusive. To shed more light on this conflicting issue, we test the following hypothesis based on the prediction of the agency theory:

Hypothesis 3a. Ownership concentration is inversely associated with bank risk-taking.

Previous studies report that government control is subject to greater agency conflicts in countries with weak legal and regulatory institutions (see, e.g., Haw et al. 2010). Likewise, government ownership brings inefficiency because of conflicts

\footnotetext{
${ }^{2}$ In regard to the Basel Accords, both Basel I and II forced the banks to hold at least level of total capital to risk-weighted assets equal to $8 \%$. Since 2010, a third accord namely Basel III has come into play. This accord has increased capital requirement from 8 to $10 \%$ along with taking some other initiatives. Basel III requires banks to reduce the value of Tier 2 and improve the value of Tier 1 because Tier 1 represents capital of good quality.
} 
between social objectives and political interests, bureaucracy and corruption, and interest group politics. However, since government ownership in the financial sector is beneficial in countries with underdeveloped institutions, one may expect a positive influence on bank risk-taking. Accordingly, Agoraki et al. (2011) and Lassoued et al. (2016) find that foreign ownership reduces banks' risk-taking behavior in emerging economies. Based on these previous findings of ownership effect, we test the following hypothesis:

Hypothesis 3b. Government ownership has a positive effect on bank risk, whereas foreign ownership is expected to reduce bank risk-taking.

Laeven and Levine (2009) posit that the impact of bank regulations on bank risktaking is largely dependent on a bank's ownership structure, while Haw et al. (2010) claim that country-level institutions play an important role in reducing the detrimental effect of concentrated control. Haque (2018) reports that the ownership structure of banks in the MENA region is highly concentrated since the largest shareholders of the sampled banks own around 52\% of shares; foreign shareholding is also reasonably high $(31 \%)$. However, the previous studies focusing on regulatory effects does not differentiate between Islamic and conventional banking systems that coexist in the MENA region. Since the level of ownership concentration is higher in CBs, whereas a larger share of government ownership characterizes IBs (Ghosh, 2017), we expect the effect of regulation to be different between two banking systems, depending on the ownership structure. To test this assumption, we develop the following hypothesis:

Hypothesis 4. The effect of regulation on bank risk-taking behavior of CBs and IBs depends on the type of ownership structure prevailing in each banking system.

\section{Data and methodology}

\subsection{Sample selection and data description}

This study is based on an unbalanced panel dataset of 3150 observations from 225 banks in 18 MENA countries, including the six GCC countries (Bahrain, Kuwait, Oman, Qatar, Saudi Arabia, and the United Arab Emirates), covering a period of 14 years (2005-2018). We selected the period from 2005 to 2018 based on the available data that allows us to construct regulatory measures for supervisory power, capital adequacy, restrictions on bank activities, and private monitoring. The accounting data are collected from the database of Orbis Bank Focus (Bureau Van Dijk), together with the annual reports of the banks included in the sample. We use the World Bank database on bank regulation and supervision (Barth et al. 2001a, b, 2004, 2008) and the World Bank's bank regulation and supervision survey in $2011^{3}$

\footnotetext{
3 The Bank Regulation and Supervision Survey (Survey IV), carried out by the World Bank, is a unique source of comparable worldwide data on how banks are regulated and supervised around the world. The current fourth round of the survey started in 2011 and was completed in 2012. It provides information on
} 
Table 1 Composition of banks by country and type

\begin{tabular}{|c|c|c|c|c|c|c|c|}
\hline Country/Banks & Total & Conventional & Islamic & Listed & Unlisted & $\begin{array}{l}\text { Average no. of } \\
\text { years of observa- } \\
\text { tions }\end{array}$ & $\begin{array}{l}\text { Total } \\
\text { obser- } \\
\text { vations }\end{array}$ \\
\hline Algeria & 9 & 9 & 0 & 0 & 9 & 10.25 & 126 \\
\hline Bahrain & 20 & 9 & 11 & 11 & 9 & 12.05 & 280 \\
\hline Egypt & 25 & 23 & 2 & 10 & 15 & 12.11 & 350 \\
\hline $\begin{array}{l}\text { Iran (Islamic Repub- } \\
\text { lic of) }\end{array}$ & 11 & 0 & 11 & 7 & 4 & 10.45 & 154 \\
\hline Iraq & 7 & 5 & 2 & 6 & 1 & 11.31 & 98 \\
\hline Israel & 8 & 8 & 0 & 6 & 2 & 12.50 & 112 \\
\hline Jordan & 15 & 12 & 3 & 13 & 2 & 12.43 & 210 \\
\hline Kuwait & 11 & 5 & 6 & 11 & 0 & 12.75 & 154 \\
\hline Lebanon & 23 & 22 & 1 & 5 & 18 & 10.27 & 322 \\
\hline Morocco & 8 & 8 & 0 & 6 & 2 & 11.62 & 112 \\
\hline Oman & 7 & 6 & 1 & 6 & 1 & 12.67 & 98 \\
\hline Palestinian Territory & 4 & 2 & 2 & 1 & 3 & 13.00 & 56 \\
\hline Qatar & 10 & 6 & 4 & 8 & 2 & 13.18 & 140 \\
\hline Saudi Arabia & 13 & 8 & 5 & 10 & 3 & 11.99 & 182 \\
\hline Syrian ArabRepublic & 12 & 9 & 3 & 9 & 3 & 12.90 & 168 \\
\hline Tunisia & 13 & 11 & 2 & 8 & 5 & 12.13 & 182 \\
\hline United Arab Emirates & 25 & 16 & 9 & 16 & 9 & 12.22 & 350 \\
\hline Yemen & 4 & 3 & 1 & 0 & 4 & 10.14 & 56 \\
\hline Total & 225 & 162 & 63 & 133 & 92 & 11.89 & 3150 \\
\hline In percentage & 100.00 & 72.00 & 28.00 & 59.11 & 40.89 & & \\
\hline
\end{tabular}

The total sample includes 225 banks in 18 countries in the MENA region. The analysis uses countryspecific and bank-level data over a period of 14 years (2005-2018). The table shows the total number of banks, the number of conventional banks (CBs) and Islamic banks (IBs) per county, the number of listed and unlisted banks, and the average number of years of observation. The last column represents the total number of observations per country

(published in 2012) to construct regulatory measures for supervisory power, capital adequacy, restrictions on bank activities, and private monitoring. Agoraki et al. (2011) argue that these indices can be more informative than dummy variables to construct a more harmonized measure. ${ }^{4}$

Table 1 provides sample statistics that include the total number of banks in each country, the number of Islamic and conventional banking institutions, and the number of listed and unlisted banks. In addition, it contains information for the average

\footnotetext{
Footnote 3 (continued)

bank regulation and supervision for 143 jurisdictions. The survey is available at: http://faculty.haas.berke ley.edu/ross_levine/Papers/Bank_Regulation_and_Supervision_Around_the_World_15JAN2013.pdf.

4 We also use other secondary data sources such as World Bank Development Indicators, International Financial Statistics, and annual reports of the MENA countries' central banks to gather macro-economic data.
} 
number of years of observations per country. The last column reports that the dataset contains 3,150 bank years of observations for the various financial variables used in this study. The data in Table 1 show that 163 banks (or $72.0 \%$ ) in the sample are conventional, and the rest are Islamic. The number of banks listed on different national and regional stock exchanges is 133 (or 59.1\%). To moderate the influence of outliers, we winsorize the top and bottom 1 per cent of observations for all bankspecific variables and expressed them in percentage terms.

\subsection{Empirical model}

Since variables such as regulatory measures and ownership are considered to be significant determinants of banks' financial stability and may have a differential effect on IBs risk behavior, we include them as explanatory variables in our analysis. This study uses a dynamic panel data model and employs the bank-level and countrywise characteristics as control variables (see Appendix A). The basic framework for our analysis is:

$$
\begin{aligned}
& Y_{i t}=\beta_{0}+\beta_{1} \times \gamma_{i, t-1}+\beta_{2} \times \text { Regul }_{i t}+\beta_{3} \times \text { Owner }_{i t}+\beta_{4} \times X_{i t}+\beta_{5} \times D_{t}+u_{i t} \\
& Y_{i t}= \beta_{0}+\beta_{1} \times \gamma_{i, t-1}+\beta_{2} \times \text { Regul }_{i t}+\beta_{3} \times \text { Owner }_{i t}+\beta_{4} \\
& \times\left(\text { Regul }_{i t} \times \text { Owner }_{i t}\right)+\beta_{5} \times X_{i t}+\beta_{6} \times D_{t}+u_{i t}
\end{aligned}
$$

In Eq. (1), $\mathrm{Y}_{i t}$ is a measure of risk of bank $i$ in year $t$, Regul $_{i t}$ and $O w n e r_{i t}$ are the explanatory variables (respectively, regulation and ownership), $X_{i t}$ is a vector composed of bank-specific control variables and macroeconomic indicators, and $D_{t}$ is a vector of dummy variables that includes an ISLAMIC dummy variable that equals one if a bank is Islamic, and zeroes otherwise, and a crisis time dummy (CRISIS) that takes the value of one for the years 2008-2009, and 0 otherwise. ${ }^{5}$ We also control for year and country fixed effects in each model. Next, we examine the effect of interactions between bank regulation and ownership on bank risk-taking. Accordingly, Eq. (2) incorporates interaction terms between different measures of bank regulation and ownership $\left(\right.$ Regul $_{i t} \times$ Owner $\left._{i t}\right)$ together with regulation and ownership as standalone variables, and all the explanatory and control variables of Eq. (1). ${ }^{6}$

We use fixed effect/random effect specifications and perform a Hausman test where the null hypothesis is that the preferred model is random effects vs. the alternative fixed effects. The choice between random and fixed effects specification depends on the Prob $>$ chi $^{\wedge} 2$ being more or less than 5\%, respectively. Note that in a panel data framework, Eqs. (1) and (2) specify dynamic structures, and therefore, endogeneity, autocorrelation, and heteroscedasticity problems may exist. We adopt

\footnotetext{
5 We follow the work of Abedifar et al. (2013) and Beck et al. (2013) and consider 2008-2009 as the crisis period.

6 To capture the effect of global financial crisis (GFC) and big financial institutions effects, we estimate a modified version of Eqs. (1) and (2) where we include an interaction variable of either regulation with GFC dummy or regulation with size dummy.
} 
the Generalized Method of Moments (GMM) estimator developed by Arellano and Bond (1995) to account for such potential issues as part of our robustness checks (see Sect. 5 below). Finally, we estimate the level of correlation amongst regulatory indices, ownership variables, and other important variables to identify if there is any multicollinearity problem. There is no significant correlation between regulatory variable and ownership measures and between regulation/ownership indicators and other independent variables. Hence, the correlation matrix (not presented here to conserve space) suggests that our estimation results do not seem to suffer from multicollinearity problems.

\subsection{Dependent variables}

Unlike our predecessors, we examine both the credit and insolvency risk of banks in the MENA region. We follow Bitar et al. (2016) and use the ratio of loan loss reserves to gross loans (LLR/GL) as a proxy for credit risk. This variable represents managers' assessment of the quality of the loan portfolio, including performing and non-performing loans (Abedifar et al. 2013). Loan loss reserve considers the past performance and the expectation for future performance of the existing loan portfolio. Its periodic adjustment is reflected in the income statement in the form of loan loss provision. Usually, higher levels of reserves suggest greater banking risk (Altunbas et al. 2007; Lee and Hsieh, 2013). For robustness purposes, we also use non-performing loans to gross loans (NPL/GL). Regarding insolvency risk, we employ a widely used measure of this risk, namely accounting $Z$-score, defined as $Z=(\mathrm{ROA}+\mathrm{EA}) / \sigma(\mathrm{ROA})$, where ROA is the return on assets, $\sigma(\mathrm{ROA})$ is the standard deviation of ROA, and EA is the ratio of equity to assets. This measure is often used in empirical studies to determine the risk and financial stability of a bank (Boyd et al. 2006; Demirgüc-Kunt and Huizinga 2010; González et al. 2017). This study calculated the $Z$-score variable for each bank in the sample over the sample period studied (2005-2018). ${ }^{7}$ Since the $Z$-score ratio calculates the distance to the insolvency of a bank, a higher Z-score implies a lower probability of default or, in other words, greater financial stability. We follow the previous research (Barry et al. 2011; Haque 2018; Lepetit et al. 2008) in using portfolio risk (PR) as an alternative measure of insolvency risk. It is measured by the ratio of return on assets (ROA) to the standard deviation of $\mathrm{ROA}^{8}$

\footnotetext{
7 The previous research uses either 3-year (Danisman and Demirel, 2019) or 5-year windows (Beltratti and Stulz, 2012); in this study we use 5-year rolling time windows in computing standard deviation of ROA to consider variability in the denominator. Since the $Z$-score is highly skewed, a natural logarithm transformation is used.

${ }^{8}$ Originally, we have used volatility in equity return (EV) as a measure of the bank level of risk. This variable is computed as the average standard deviation of the bank's equity returns estimated using annualized total returns for each year of the sample period. The regressions with this variable include only listed banking institutions, so we decided to drop it from our analysis.
} 


\subsection{Independent and control variables}

The choice of variables used in our analysis is primarily guided by previous literature and data availability. These variables include independent variables (regulatory measures and ownership) and control variables (institution, efficiency ratio, liquidity ratios, capital ratios, size, macroeconomic variables, and dummy variables that capture year or country characteristics). All independent and control variables are described in Appendix A.

Following previous research (Beltratti and Stulz 2012; Haque and Brown 2017; Mateev and Bachvarov 2018), we use indices for the power of the regulators, oversight of bank capital, restrictions on bank activities, and private monitoring of banks. The official is an index of the power of the commercial bank supervisory agency, capital is an index of regulatory oversight of bank capital, restrict is an index of regulatory restrictions on the activities of banks, and private monitoring is an index of monitoring on the part of the private sector (please, refer to Appendix A). In line with Hypothesis 1 and 2, capital regulations and restrictions on bank activities index are negatively associated with bank risk-taking. Similar effect on bank risk is expected for private monitoring, whereas official supervisory power should have a positive impact on bank risk-taking. The regulation variables come from Barth et al. (2001a, b, 2004, 2008) and the World Bank's bank regulation and supervision survey in 2011, downloaded from the World Bank website. It is important to note that the regulation variables concern depository banks and not investment banks and do not capture regulators' stance either (Beltratti and Stulz 2012).

According to Haque (2018), two types of ownership variables can be used to measure internal corporate governance. These include the concentration of ownership as measured by the percentage of shareholding of the largest shareholder and the types of ownership structure, that is, government shareholding and foreign ownership. In accordance with previous research (Iannotta et al. 2007; Shehzad et al. 2010), we expect ownership concentration to positively affect bank risk-taking, whereas government ownership may induce bank risk-taking behavior. Likewise, we follow Agoraki et al. (2011) and Lassoued et al. (2016) to predict that foreign ownership will reduce bank risk-taking in the MENA region.

We follow Shehzad et al. (2010), Forssbæck (2011), and Haque and Brown (2017), among others, in using several bank-specific characteristics known to be significant determinants of bank behavior. These include bank deposits, net loans to assets, Tier 1 ratio, funding fragility, income diversity, other earning assets, bank size, and liquid assets, as control variables in the regression models. The expected signs and magnitude are reported in Appendix A. While some previous studies (see e.g., Bitar et al. 2016) use cost-to-income (CIR) as the dependent variable in their analysis of bank profitability, others use cost efficiency as the independent variable (Bashir and Hassan 2017). In this study, we use CIR to control for potential differences in bank efficiency between the two groups of banks (Islamic and conventional). The variable 'institution' is the simple average of six indicators reported by Kaufmann et al. (2008): voice and accountability, political stability and absence of violence, government effectiveness, regulatory quality, the rule of law, and control of corruption. A higher value of the index indicates a better institutional environment 
in the sample country. Finally, we use GDP growth, the natural logarithm of real GDP per capita (as an alternative measure), and inflation to control for macroeconomic differences across the countries in our sample (Schaeck and Cihák 2007; Louati et al. 2015; Moudud-Ul-Huq 2020).

\section{Empirical results and discussion}

\subsection{Descriptive statistics and univariate analysis}

Table 2 compares different variables used in our analysis across the two banking systems (Islamic and conventional). We use two alternative measures for bank credit risk (LLR/GL and NPL/GL) and distance-to-default (Z-score) and portfolio risk (PR) as measures of bank insolvency risk.

We observe a statistically significant difference between CBs and IBs in all measures of bank risk-taking (the mean difference is significant at the usual levels of significance) except for the non-performing loans to gross loans ratio. The estimated value of profitability ratio (ROA) shows that $\mathrm{CBs}$ demonstrate a much better performance over the sample period of 14 years than IBs (21.91 vs. 7.67\%). However, when bank profitability is measured by net interest margin (NIM), both banks show negative results, with IBs performing much worse than CBs. Our results are in line with Olson and Zoubi (2017), who find that during and after the global financial crisis in 2007-2008, the IBs performance has significantly deteriorated. Furthermore, the data in Table 2 indicate that IBs have a higher level of inefficiency measured by the cost-to-income ratio (CIR) than CBs (54.46 vs. $47.37 \%$ ); however, the means difference between the two samples is statistically insignificant.

Table 2 also displays the regulatory measures that represent macro-prudential regulation. Though these variables carry similar values across the two samples (Islamic and conventional), we observe that the mean difference is statistically significant at the $1 \%$ significance level. This further supports our hypothesis that the effect of regulations on bank risk-taking may be different between the two banking systems (CBs and IBs). Following the approach of Kaufmann et al. (2008), we create a composite index, institution, which is the mean of six variables for each country in the sample (see Appendix A). A higher value of the index indicates better institutions. The median value of this index for the total sample as well as for each group of banks is negative, which can be a signal for the unhealthy institutional environment in the MENA countries.

Following Haque and Brown (2017), we use three indicators of ownership structure-concentrated ownership as measured by the percentage of shareholding of the largest shareholder, government shareholding, and foreign ownership. IBs are typically domestically owned, and the data in Table 2 support this convention; the percentage of foreign ownership in our sample of IBs is only $35.8 \%$. The percentage of ownership concentration is much larger in the group of CBs than in IBs (49.85 vs. 43.24). The high percentage of concentrated ownership in both types of banks is in line with the previous studies' observations for the MENA region (Farazi et al. 2011; Haque and Brown 2017). Furthermore, around 24\% of all banks in the sample 


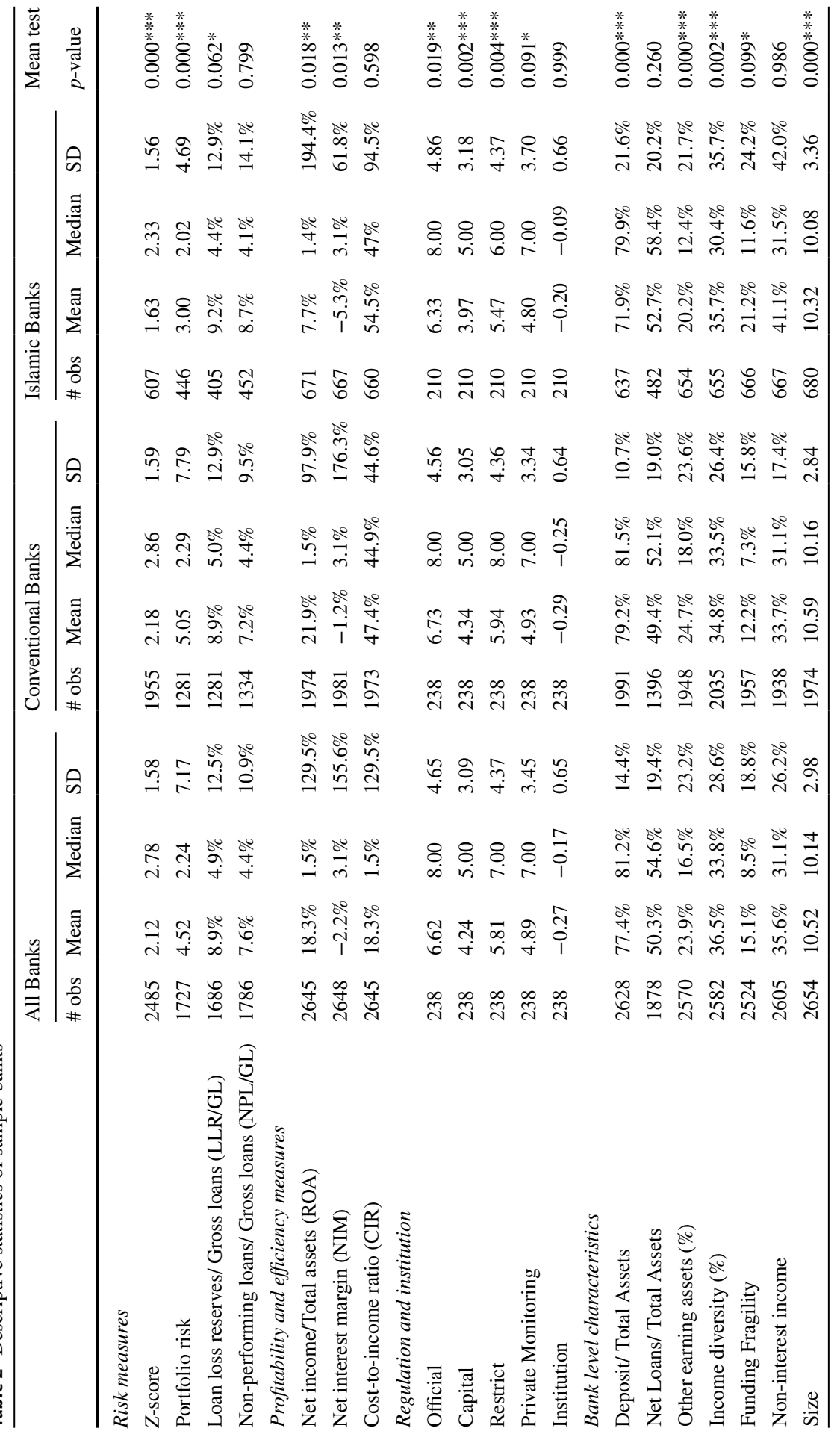




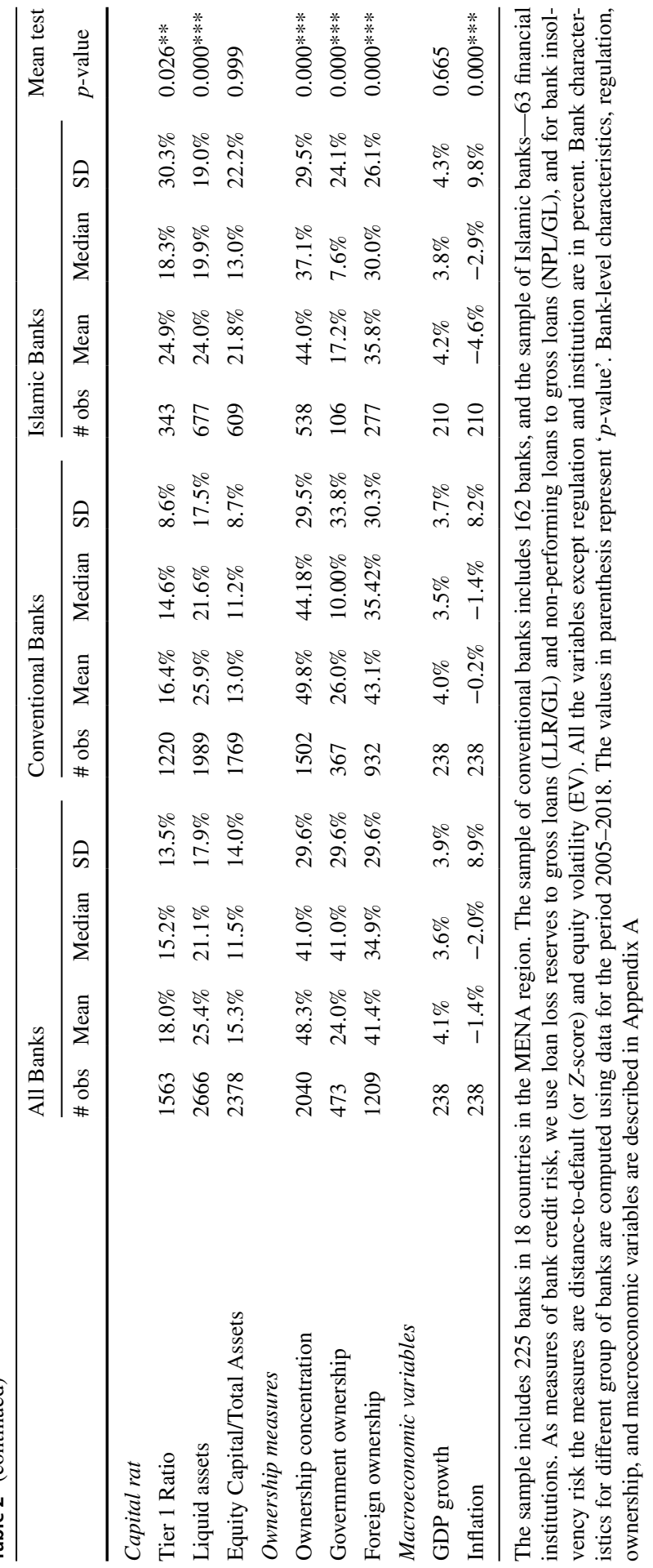


are government-owned, with IBs having a lower presence of government ownership. All indicators of the ownership structure are statistically different between the two samples at the $1 \%$ level of significance.

Finally, we compare the bank-level characteristics between the two samples and find that the individual bank variables are significantly different between the two banking systems (except net loans to total assets and non-interest income). Regarding the asset size, CBs and IBs are of almost equal size. Additionally, IBs have a lower deposit to assets ratio but outperform CBs regarding net loans to total assets (52.66 vs. 49.44\%). Data in Table 2 indicate that income diversity and non-interest income ratios are higher in the sample of IBs; however, funding fragility for IBs much exceeds the same indicator for CBs (25.79 vs. $12.95 \%)$. We also observe that capital ratios are significantly different between the two groups of banks. More specifically, we find that, in the sample of IBs, the Tier 1 and EC/TA ratios much exceed those for CBs; however, IBs have a lower level of liquid assets (24.01 vs. $25.92 \%)$. These results align with the previous research findings on banks in the MENA region (Olson and Zoubi** 2016; Mateev and Bachvarov 2021).

According to Grassa (2012), Islamic profit-loss sharing products are associated with higher insolvency risk than products offered by conventional banks, and this type of risk has a more unfavorable impact on bank performance during a prolonged crisis. Table 2 confirms this finding; the insolvency risk measured by distance-todefault (or Z-score) is significantly different between the two groups of banks, with CBs much less risky than IBs (2.18 vs. 1.63). We also observe that IBs have higher credit risk too.

\subsection{The effect of regulation and ownership on bank credit risk}

In this section, we investigate whether the effect of regulation on bank risk-taking depends on the type of ownership. To test this hypothesis, we use an interaction term between regulatory variables and each ownership indicator variable. We expect regulatory measures to significantly influence the risk behavior of banks in the MENA region; however, this effect may depend on the type of ownership structure prevailing in each banking system.

The outputs of the regression analysis for both credit and insolvency risks are reported in Table 3. Models 1 to 4 shows estimation results for bank credit risk against individual regulation and ownership variables, as well as the interaction terms as specified in Eq. (2). We find that the official supervisory index is positively associated with bank credit risk, which supports our second hypothesis (H2). This finding is in line with the 'private interest view' of bank regulation, which suggests that powerful supervisors can influence banks to rent loans to maximize private benefits as they have little incentives to restrict bank risk-taking in the greater interest of the depositors and general public (Beck et al. 2006). In line with our second hypothesis, the private monitoring measure is negatively associated with bank credit risk, supporting the 'public interest view' of bank regulation. This hypothesis postulates that increased market discipline and better monitoring are expected to reduce the negative effects of a concentrated banking market and enforce the prudent 


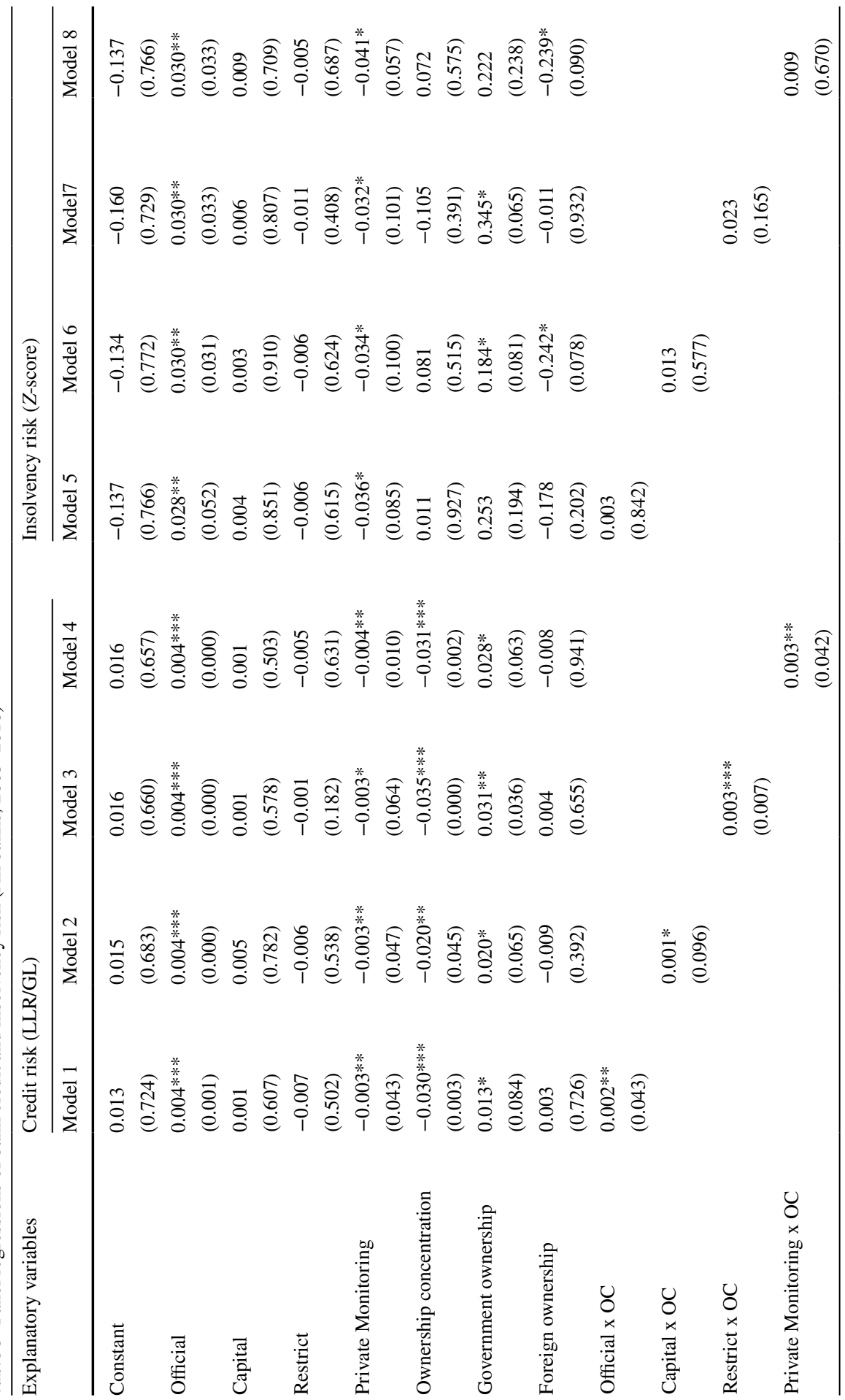




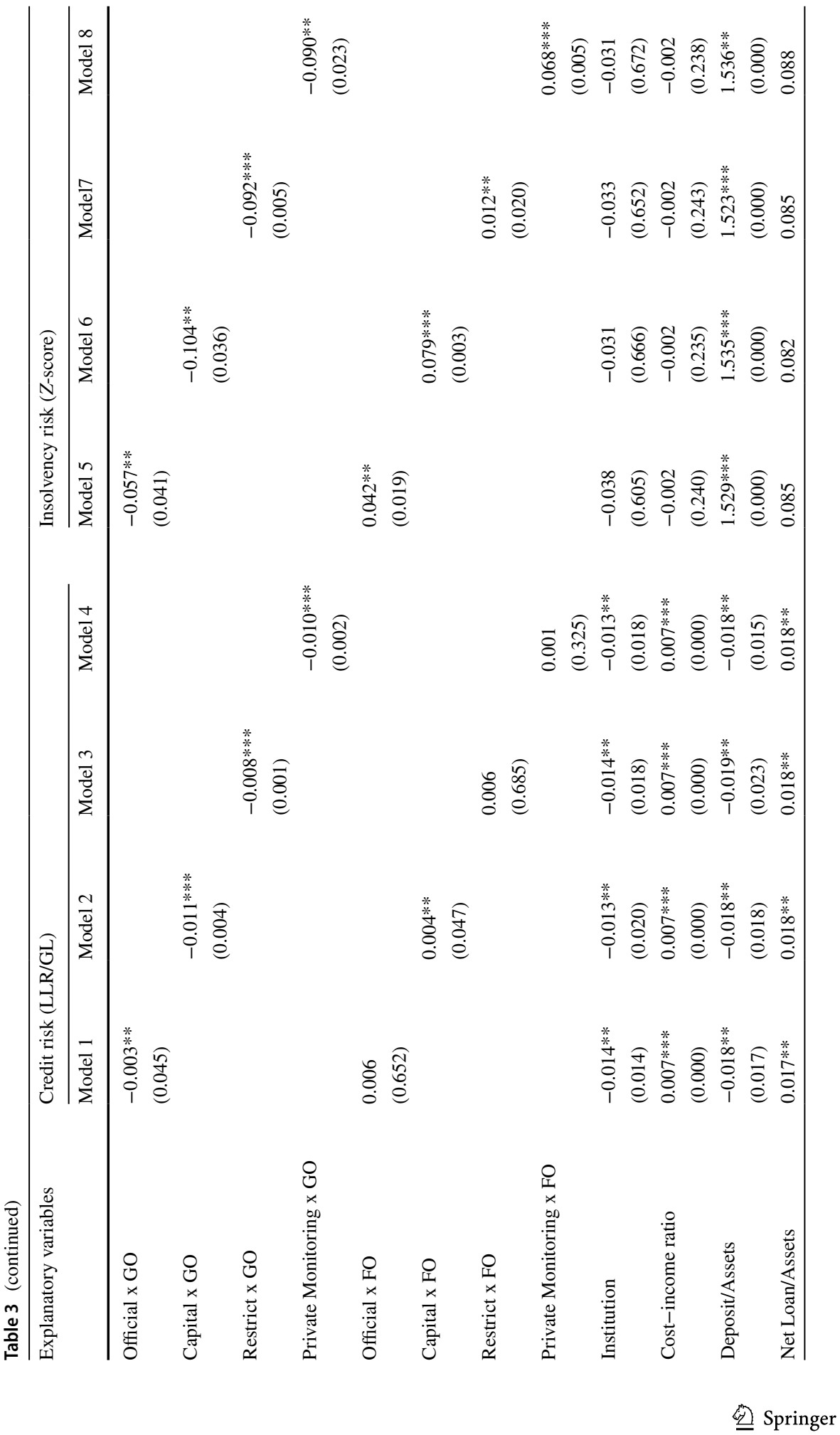




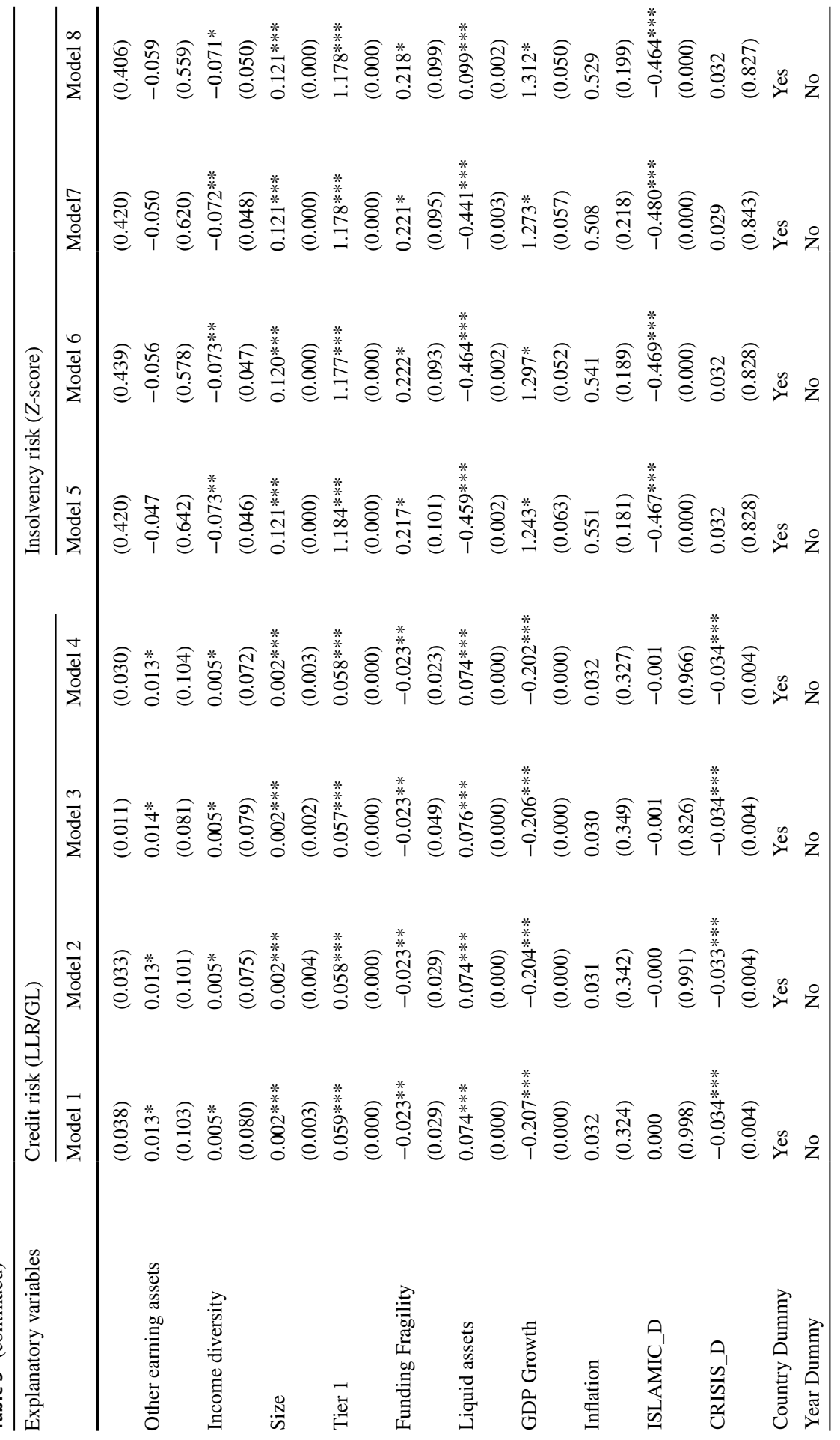




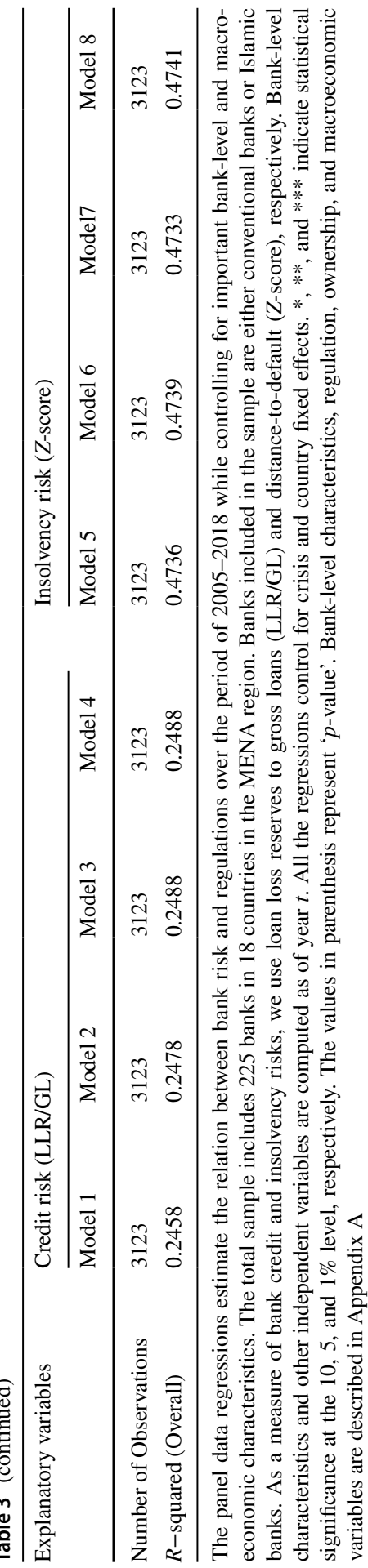


risk-taking behavior of banks. Therefore, regulatory initiatives in the MENA countries related to the disclosure of reliable, comprehensive, and consolidated information on bank activities, including their risk management practices, should be tailored in a way to restrict banks from excessive risk-taking.

The results presented in Table 3 indicate that regulatory capital requirements and the restrictions on bank activities do not significantly affect bank risk-taking. Thus, we are not able to provide evidence in support of our first hypothesis (H1).

Previous studies (Srairi 2013; Lassoued et al. 2016; Sarker and Nahar 2017) find that ownership structure is an important determinant of bank risk in the MENA region. Bases on these findings, we hypothesize that ownership concentration and foreign ownership should positively impact bank risk-taking, whereas government ownership is expected to increase bank risk-taking. The results in Table 3 support this view. In line with Hypothesis 3a, ownership concentration is negatively associated with bank credit risk. This finding tells us that banks with high level of concentrated ownership are less inclined to pursue riskier strategies. The effect of foreign ownership is statistically insignificant, which does not support Hypothesis $3 \mathrm{~b}$ and the general view that foreign ownership reduces bank risk-taking in emerging economies (Agoraki et al. 2011; Lassoued et al. 2016). The government ownership effect is positive but marginally significant which partially support Haque (2018) who reports insignificant influence of regulatory and ownership measures (except foreign ownership) on bank credit risk for his sample of banks.

Next, we test the hypothesis that the effect of regulations on bank risk-taking may depend on the type of ownership structure. Therefore, in each model in Table 3, we introduce successively an interaction term that is a product of each regulatory measure and the ownership variables. The results show a significant interaction effect between all the regulatory measures and the ownership concentration variable (except capital regulation). Regulatory effects seem to be more pronounced for banks with a higher level of ownership concentration. The results for government ownership indicate that the impact of regulatory measures will be mitigated for banks with high level of government presence in their ownership structure. An opposite effect is observed for foreign ownership; banks with a strong foreign presence will increase their credit risk level in response to an increase in the regulatory pressure (e.g., increase in the minimum capital requirements). We may conclude that the increase in regulatory requirements will enforce government owned banks to decrease their level of credit risk, whereas banks with high level of ownership concentration and foreign presence will pursue risky strategies to mitigate this effect.

To control for the overall quality of the institutional environment in our sample countries, we introduce in each model a composite variable, institution. We find that this variable is strongly significant and negative in all the regressions. Therefore, better quality of the institutional environment will be associated with lower risk. The policy implication of this finding is that a combination of better institutional quality and stringent regulation and supervision will enforce the prudent risk-taking behavior of banks in the MENA region.

Since the previous research on the MENA region (Haque, 2018) has reached inconclusive results in regard to the effect of regulations on banks' insolvency risk, we further investigate this issue and report our results in Table 3 (see Models 5 to 8). 
First, we consider the individual effect of regulatory measures on bank risk-taking behavior. In line with the 'public interest view,' we find that the official supervisory index employs a positive association with the insolvency risk measure (distance to default or Z-score). Since this is an inverse measure of insolvency risk, this result informs us that an increased level of supervisory power will reduce the level of insolvency risk. In contrast, the relationship between private monitoring and a bank's insolvency risk measure is negative, which supports the 'private interest view' of bank regulation in that the increased pressure for market disclosure increases risk of default. These results align with our second hypothesis (H2).

We also examine the interaction effect of regulatory measures and ownership on insolvency risk. The regression results confirm our expectations that the ownership structure of a bank strongly moderates the relationship between regulatory measures and risk-taking (e.g., government and foreign ownership). In contrast to Haque (2018) finding that the interaction between supervisory power (activity restrictions index) with ownership concentration shows a highly significant positive (negative) association with both default and portfolio risks, our results show that the moderating effect of ownership concentration is insignificant. Two main reasons can explain our results. First, independent but not empowered supervisory authorities in the MENA countries might be unable to deal with excessive political interference and various operational inefficiencies that increase banks' overall risk. ${ }^{9}$ Second, despite the recent progress with bank-level compliance with the Basel III provisions (e.g., capital regulations and market-oriented disclosures), the regulatory reforms do not seem to show the desired outcome in reducing bank risk, and these effects are dependent on activity restrictions and/or ownership concentration in shaping the risk-taking behavior of banks as reported by Haque (2018).

In Table 3, we control for a number of bank-level and country-specific characteristics and find them all (except inflation) to be strong determinants of bank risk-taking behavior. Though the crisis dummy variable is significant, the negative sign of the estimated coefficient is counter-intuitive since one should expect banks to keep a higher level of loan loss reserves during the crisis period of 2008-2009 than in the non-crisis periods. Thus, our finding challenges the notion that the buffer created by loan loss reserves lowers bank risk of failure. In this context, $\mathrm{Ng}$ Jeffrey and Roychowdhury (2013) find that larger loan loss reserves in 2007 are associated with an increased risk of bank failure in 2008-2009, but only for banks that are allowed to add bank loans loss reserves as Tier 2 capital.

\subsection{Is there a differential effect of regulation and ownership on IB's risk-taking?}

The results reported in Tables 3 above do not provide a clear answer to the question of whether the effect of regulation and ownership on bank risk-taking is significantly different between CBs and IBs. To the best of our knowledge, we are the first to

\footnotetext{
9 According to Ayadi and De Groen (2013) and Mohseni-Cheraghlou (2012) the supervisory authorities of several GCC countries can act with greater independence, but they do not have the adequate authority to replace inefficient management or to declare a bank insolvent.
} 


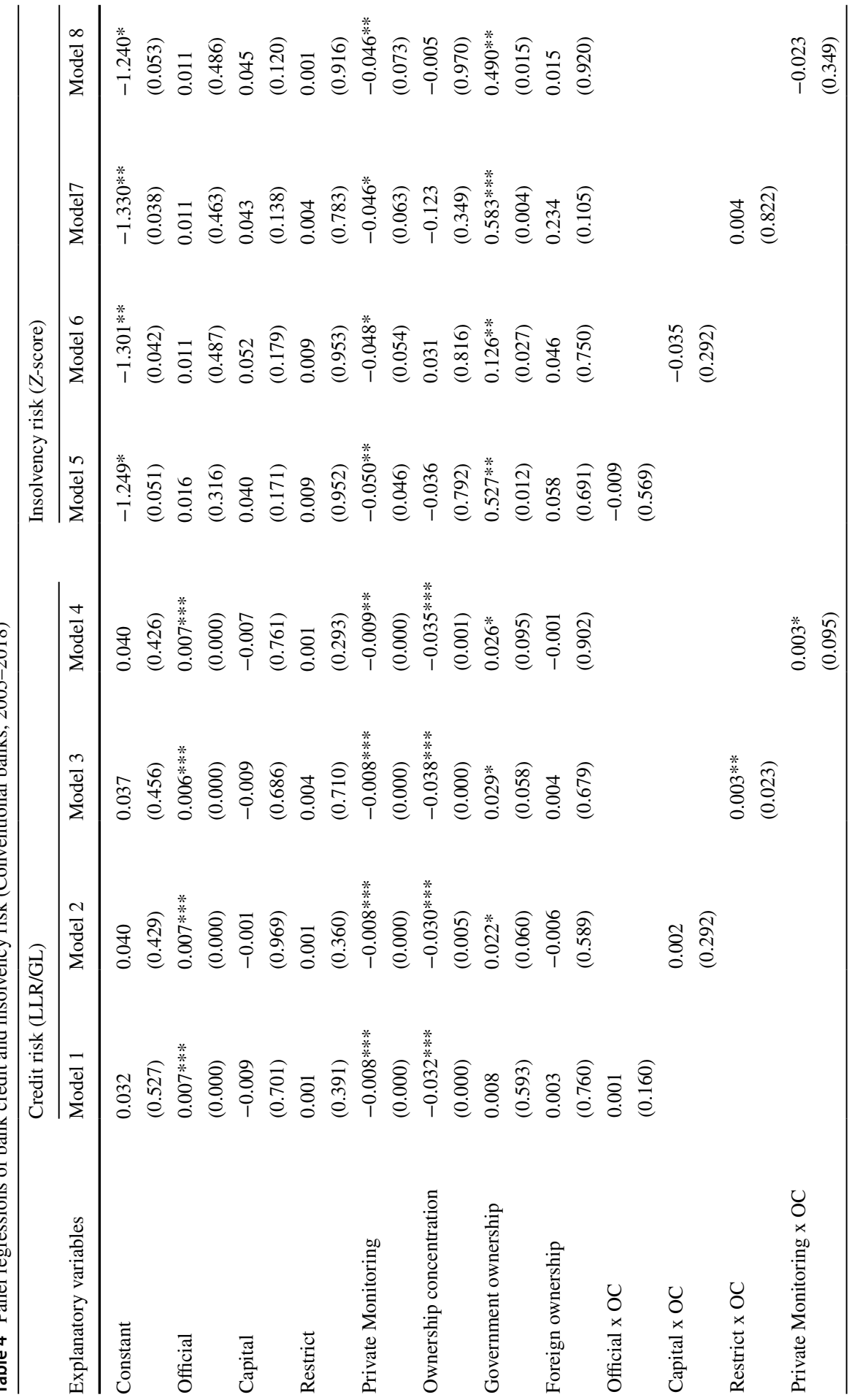




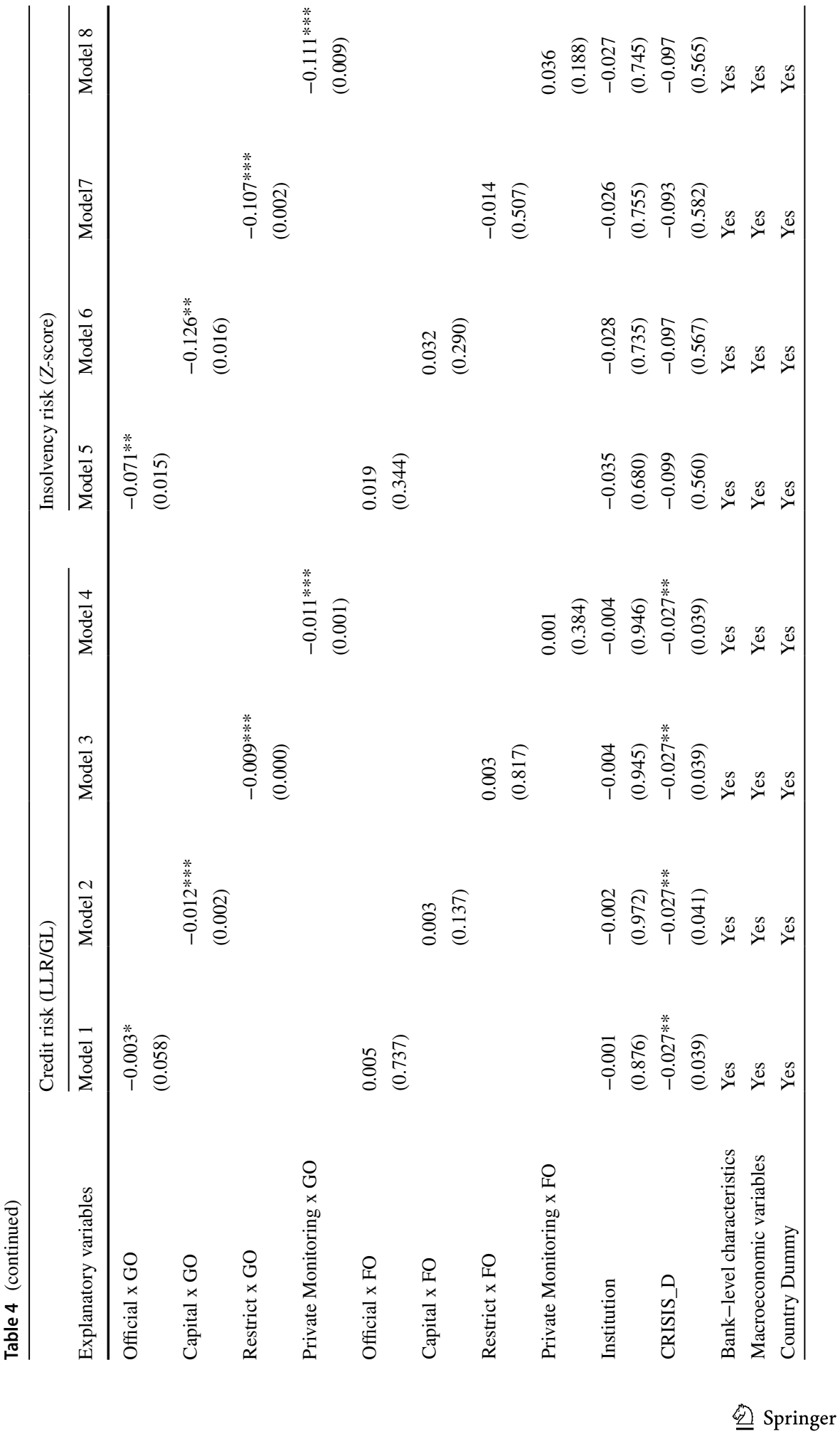




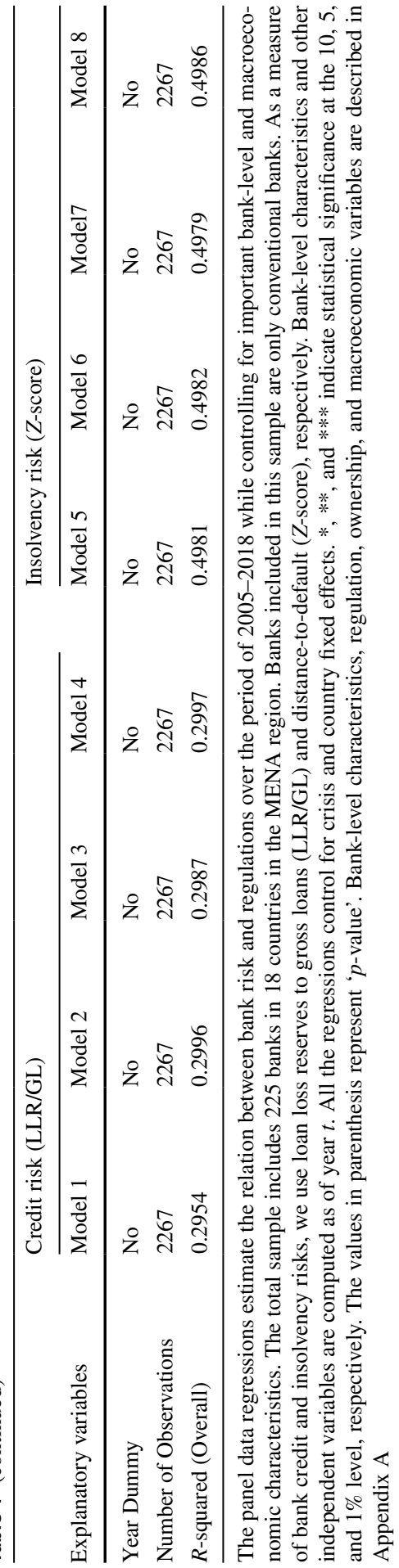




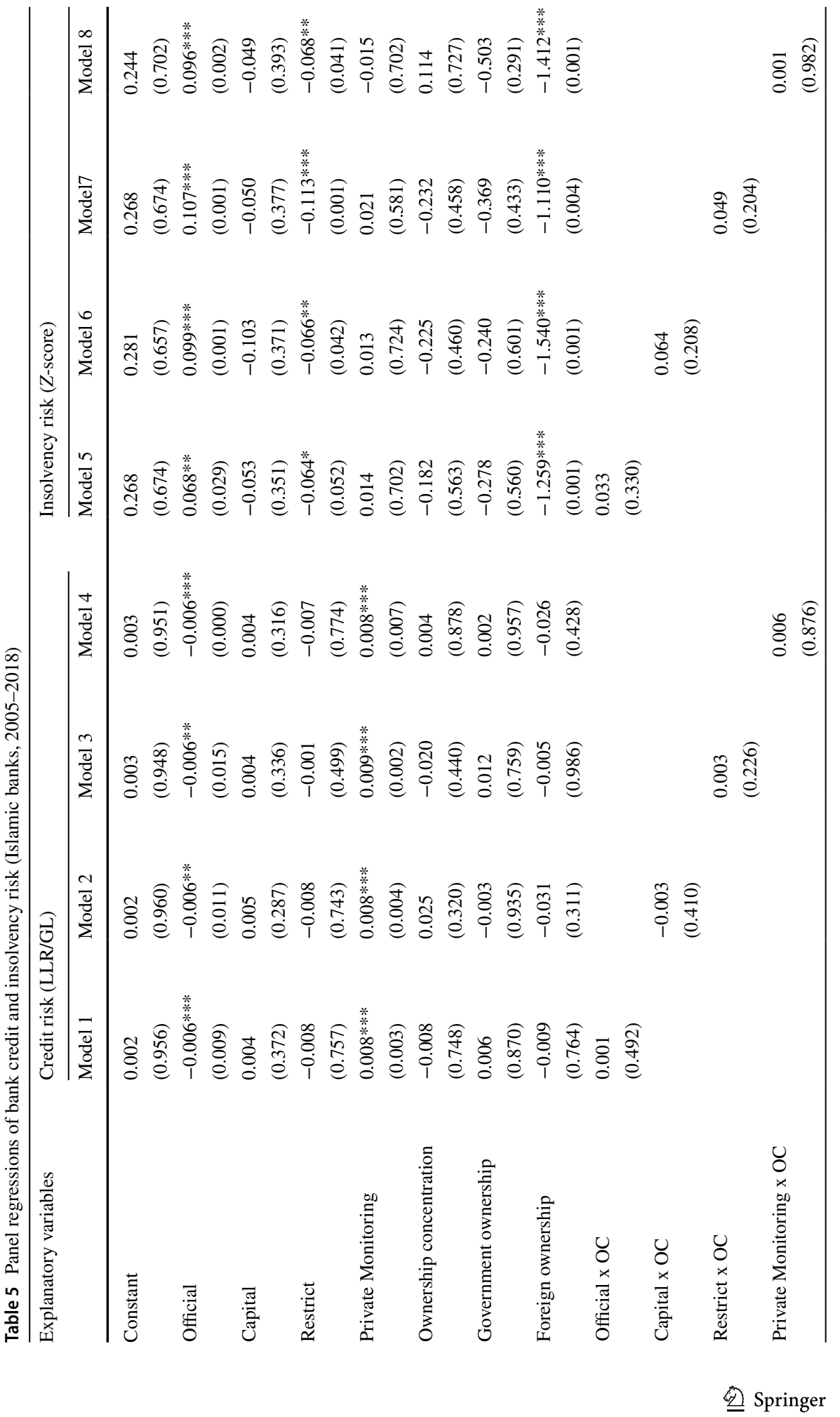




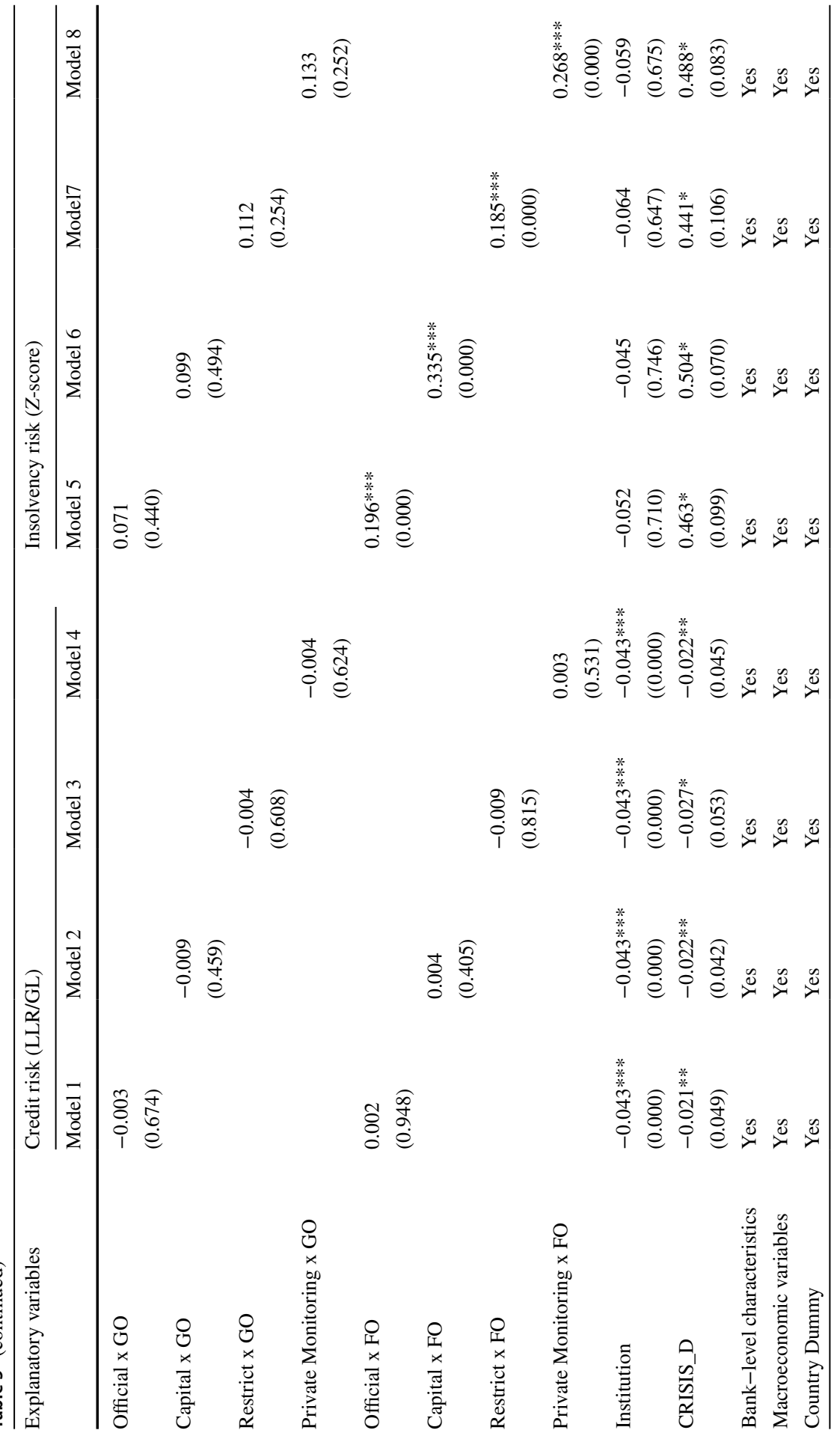




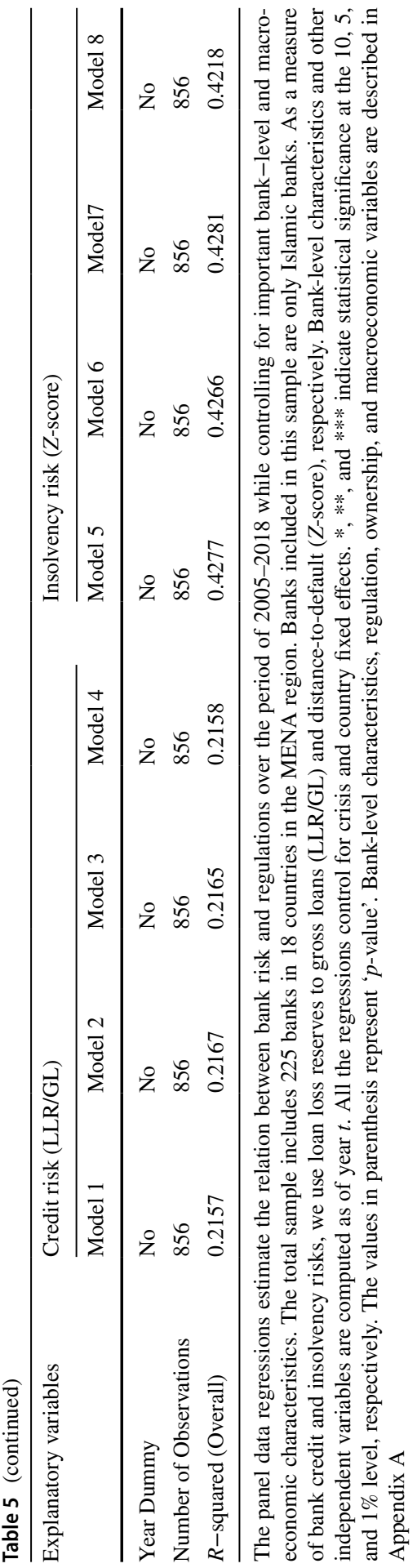


address this important issue with strong policy implications. Therefore, we run our analysis separately for the samples of CBs and IBs, and report our results in Tables 4 and 5 , respectively.

Table 4 shows a significant influence of the official supervisory index and private monitoring in the sample of CBs (see Model 1). Specifically, the official supervisory index is positively associated with bank risk-taking, while private monitoring tends to have a negative relationship with credit risk; these results support the private and public interest view of bank regulation, respectively. We also observe that CBs with a high level of concentration of ownership are keeping a lower level of credit risk, whereas governance ownership and foreign presence in a bank's ownership structure seem to have no impact on the risk-taking behavior of CBs.

From Table 5 which displays the results for IBs, we observe opposite effects for the official supervisory index and private monitoring, which contradicts our second hypothesis $(\mathrm{H} 2)$. This can be explained by the fact that IBs are more likely to adopt sound risk management practices than conventional banks. This is in line with Bourkis and Nabi (2013), who point at the fact that Islamic banking institutions face extra risk because they have limitations in financing, investing, and risk management activities, and, at the same time, their financial practices are more complex. Thus, more intense banking supervision will reduce the risk-taking behavior of IBs, whereas market-based disclosure will have the opposite effect. However, the ownership structure appears to have no role in shaping the risk behavior of Islamic banking institutions, which can be explained by the fact that these banks operate under Sharia's principles.

The results in Tables 4 and 5 indicate a significant differential impact of ownership on the relationship between regulation and credit risk. For example, in the sample of $\mathrm{CBs}$, the ownership structures that moderate the relationship between regulatory measures and credit risk is government shareholding and ownership concentration (in the case of activity restrictions and private monitoring). However, in the sample of IBs, the interaction effect with ownership measures is insignificant. This finding supports the results of the univariate analysis. For example, according to Table 2, CBs have a higher level of government ownership than IBs; therefore, one may expect that regulatory effect is more pronounced for conventional banks with high level of government presence. In opposite, ownership structure does not moderate the relationship between regulation and credit risk of IBs. These findings contradict Ben Khediri et al. (2015), who argue that, since both types of banks operate in the same competitive environment and are regulated in the same way in most countries, they are likely to have similar behavior and thus similar risk management strategies. We claim that, on the opposite, the regulatory reform initiatives should be tailored differently for CBs and IBs.

We also discover significant differences in the effect of regulations and ownership on bank insolvency risk between the two banking systems. These results show that regulatory measures do have a differential impact on the risk-taking behavior of banks in the MENA region, and this effect depends on the ownership structure prevailing in each banking system. For example, the effect of regulatory measures on bank risk-taking is strongly moderated by the level of government ownership of $\mathrm{CBs}$, whereas the influence of different regulatory measures is reinforced only 
for IBs with a strong presence of foreign ownership. Since the moderating effect of ownership structure is different between Islamic and conventional banking institutions, we find a strong support to our last hypothesis (H4), which postulates that regulatory effect depends on the type of ownership structure prevailing in each banking system. This result somewhat confirms the 'global advantage hypothesis' and suggests that foreign shareholding plays a risk-stabilizing role in the banking sector of MENA countries, more specifically, the Islamic banking.

What are the policy implications of these results? Our analysis provides evidence that regulatory measures have a differential impact on IBs, and this effect is related to the type of ownership structure of a bank. For example, banks with high ownership concentration and government participation are more constrained in their risktaking behavior in countries characterized by strict private monitoring and enhanced power of supervisory authorities but less stringent capital requirements and activity restrictions. Any changes in these bank regulations are expected to significantly affect the risk-taking behavior of CBs. In opposite, IBs with a higher level of foreign ownership will have more incentives to increase their risk level in the face of increased regulatory pressure. Consequently, decision-makers and regulators in the MENA countries should not push to privatize government-owned banks, while the reduction of the entry barriers to foreign banks is likely to decrease bank risk levels when combined with appropriate regulatory reforms. Since ownership structure itself has no role to play in shaping the risk-taking behavior of IBs, regulatory pressure remains the main instrument for control over their choice of risky strategies.

\subsection{Bank risk-taking before and after the crisis}

Previous research examines if the global financial crisis of 2007-2008 moderates the effects of ownership and bank regulations on bank risk-taking. For example, Bourkhis and Nabi (2013) examine the impact of financial crisis on the soundness of Islamic and commercial banks in the MENA region and find no difference in terms of the effect of the global financial crisis on the soundness of IBs and CBs. Since this issue remains relatively unexplored, we further investigate the impact of regulation and ownership on different banking systems in the MENA region, before and after the global financial crisis. The results for credit risk are reported in Table 6 while those for insolvency risk are available in Table $7 .{ }^{10}$

The regression results in Table 6 show that in the pre-crisis period (2005-2009), regulatory measures have no significant influence on the risk-taking behavior of either bank (see Models 2 and 5). However, in the post-crisis period

\footnotetext{
${ }^{10}$ Following 2008-2009 financial crisis, we test for structural breaks in the data. However, standard tests, like the Chow test, do not apply given that the variables under consideration are non-stationary. Accordingly, we divide our sample into two sub-samples: (1) 1 Jan 2005-Dec 2009 and (2) Jan 2010Dec 2018, and test whether the cointegration relationships have changed before and after the crisis between the following groups of countries/banks: 1) CBs and IBs, and 2) MENA and GCC countries. We find that none of the cointegration relationships change in any of the tested sub-groups. This provides enough empirical evidence to assume that the dynamic relationships did not change before and after the 2008-09 global financial crisis. The results are available upon request.
} 
Table 6 Panel regressions of bank credit risk (pre-crisis and post-crisis period)

\begin{tabular}{|c|c|c|c|c|c|c|}
\hline \multirow[t]{2}{*}{ Explanatory variables } & \multicolumn{3}{|c|}{ Conventional Banks } & \multicolumn{3}{|c|}{ Islamic Banks } \\
\hline & All years & Pre-crisis & Post-crisis & All years & Pre-crisis & Post-crisis \\
\hline & Model 1 & Model 2 & Model 3 & Model 4 & Model 5 & Model 6 \\
\hline \multirow[t]{2}{*}{ Constant } & 0.019 & 0.019 & 0.053 & 0.002 & -0.014 & 0.001 \\
\hline & $(0.694)$ & $(0.335)$ & $(0.349)$ & $(0.963)$ & $(0.322)$ & $(0.977)$ \\
\hline \multirow[t]{2}{*}{ Official } & $0.007 * * *$ & 0.006 & $0.007 * *$ & $-0.006^{* *}$ & -0.002 & -0.003 \\
\hline & $(0.000)$ & $(0.930)$ & $(0.014)$ & $(0.011)$ & $(0.242)$ & $(0.966)$ \\
\hline \multirow[t]{2}{*}{ Capital } & -0.008 & 0.009 & 0.006 & 0.004 & 0.004 & $0.030 * *$ \\
\hline & $(0.718)$ & $(0.446)$ & $(0.247)$ & $(0.353)$ & $(0.243)$ & $(0.015)$ \\
\hline \multirow[t]{2}{*}{ Restrict } & 0.009 & 0.006 & 0.001 & -0.008 & 0.001 & $-0.020^{* *}$ \\
\hline & $(0.417)$ & $(0.451)$ & $(0.732)$ & $(0.763)$ & $(0.463)$ & $(0.041)$ \\
\hline \multirow[t]{2}{*}{ Private Monitoring } & $-0.008 * * *$ & -0.001 & $-0.018 * * *$ & $0.008 * * *$ & -0.002 & 0.008 \\
\hline & $(0.000)$ & $(0.292)$ & $(0.000)$ & $(0.003)$ & $(0.414)$ & $(0.273)$ \\
\hline \multirow[t]{2}{*}{ Ownership concentration } & $-0.020 * * *$ & 0.001 & $-0.025 * *$ & 0.007 & -0.005 & 0.010 \\
\hline & $(0.004)$ & $(0.635)$ & $(0.011)$ & $(0.527)$ & $(0.257)$ & $(0.570)$ \\
\hline \multirow[t]{2}{*}{ Government ownership } & -0.007 & $-0.022 * * *$ & $-0.026^{*}$ & -0.009 & -0.011 & -0.011 \\
\hline & $(0.535)$ & $(0.000)$ & $(0.101)$ & $(0.784)$ & $(0.268)$ & $(0.886)$ \\
\hline \multirow[t]{2}{*}{ Foreign ownership } & -0.005 & -0.001 & -0.003 & -0.009 & -0.006 & -0.020 \\
\hline & $(0.446)$ & $(0.661)$ & $(0.780)$ & $(0.567)$ & $(0.403)$ & $(0.380)$ \\
\hline \multirow[t]{2}{*}{ Institution } & -0.006 & 0.014 & $-0.015^{* *}$ & $-0.043 * * *$ & -0.024 & $-0.037 * * *$ \\
\hline & $(0.927)$ & $(0.135)$ & $(0.049)$ & $(0.000)$ & $(0.189)$ & $(0.008)$ \\
\hline \multirow[t]{2}{*}{ CRISIS_D } & $-0.027 * *$ & - & - & $-0.021 *$ & - & - \\
\hline & $(0.041)$ & & & $(0.051)$ & & \\
\hline Bank-level characteristics & Yes & Yes & Yes & Yes & Yes & Yes \\
\hline Macroeconomic variables & Yes & Yes & Yes & Yes & Yes & Yes \\
\hline Country Dummy & Yes & Yes & Yes & Yes & Yes & Yes \\
\hline Year Dummy & No & Yes & Yes & No & Yes & Yes \\
\hline Number of Observations & 2267 & 809 & 1458 & 856 & 305 & 551 \\
\hline$R$-squared (Overall) & 0.2954 & 0.4149 & 0.4137 & 0.2150 & 0.4592 & 0.2462 \\
\hline
\end{tabular}

The panel data regressions estimate the relation between bank risk and regulation before the crisis (2005-2009) and after the crisis (2010-2018) periods. The sample includes 225 banks in 18 countries in the MENA region. Total sample of banks is split in two groups: Conventional banks and Islamic banks. Dependent variable is loan loss reserves to gross loans (LLR/GL) as a measure of bank credit risk. Bank-level characteristics and other independent variables are computed as of year $t$. All the regressions control for year and country fixed effects. *, **, and *** indicate statistical significance at the 10, 5, and $1 \%$ level, respectively. The values in parenthesis represent ' $p$-value'. Bank-level characteristics, regulation, ownership, and macroeconomic variables are described in Appendix A

(2010-2018), the official supervisory index and private monitoring significantly influence the risk-taking behavior of CBs. Likewise, in the sample of IBs, the regulatory effects (e.g., capital regulations and the overall restrictions on bank activities) also play a significant role in the post-crisis period. This can be explained by the fact that the MENA region has made considerable progress in implementing the Basel guidelines on capital regulations, market-oriented disclosures, and 
Table 7 Panel regressions of bank insolvency risk (pre-crisis and post-crisis period)

\begin{tabular}{|c|c|c|c|c|c|c|}
\hline \multirow[b]{2}{*}{ Explanatory Variables } & \multicolumn{3}{|c|}{ Conventional Banks } & \multicolumn{3}{|c|}{ Islamic Banks } \\
\hline & All years & Pre-crisis & Post-crisis & All years & Pre-crisis & Post-crisis \\
\hline & Model 1 & Model 2 & Model 3 & Model 4 & Model 5 & Model 6 \\
\hline \multirow[t]{2}{*}{ Constant } & $-1.295 * *$ & $0.941 *$ & -0.646 & 0.181 & 0.634 & 0.491 \\
\hline & $(0.041)$ & $(0.053)$ & $(0.310)$ & $(0.780)$ & $(0.270)$ & $(0.455)$ \\
\hline \multirow[t]{2}{*}{ Official } & $0.011 *$ & 0.026 & $0.015^{*}$ & $0.098 * * *$ & $-0.113^{*}$ & -0.005 \\
\hline & $(0.088)$ & $(0.477)$ & $(0.061)$ & $(0.002)$ & $(0.083)$ & $(0.947)$ \\
\hline \multirow[t]{2}{*}{ Capital } & 0.044 & 0.024 & -0.006 & -0.067 & 0.007 & 0.004 \\
\hline & $(0.131)$ & $(0.713)$ & $(0.909)$ & $(0.242)$ & $(0.960)$ & $(0.972)$ \\
\hline \multirow[t]{2}{*}{ Restrict } & 0.007 & -0.011 & 0.014 & $-0.065^{*}$ & 0.005 & -0.060 \\
\hline & $(0.961)$ & $(0.805)$ & $(0.711)$ & $(0.051)$ & $(0.943)$ & $(-0.060)$ \\
\hline \multirow[t]{2}{*}{ Private Monitoring } & $-0.050 * *$ & -0.046 & $-0.044 * *$ & 0.018 & 0.134 & 0.091 \\
\hline & $(0.045)$ & $(0.487)$ & $(0.031)$ & $(0.638)$ & $(0.149)$ & $(0.244)$ \\
\hline \multirow[t]{2}{*}{ Ownership concentration } & -0.098 & -0.004 & -0.071 & 0.044 & $0.579 * * *$ & -0.104 \\
\hline & $(0.274)$ & $(0.975)$ & $(0.531)$ & $(0.767)$ & $(0.003)$ & $(0.604)$ \\
\hline \multirow[t]{2}{*}{ Government ownership } & 0.198 & $0.659 * *$ & -0.124 & -0.212 & $-1.017 * * *$ & 1.408 \\
\hline & $(0.190)$ & $(0.014)$ & $(0.497)$ & $(0.583)$ & $(0.009)$ & $(0.118)$ \\
\hline \multirow[t]{2}{*}{ Foreign ownership } & $0.163^{*}$ & -0.011 & 0.169 & 0.095 & 0.204 & -0.100 \\
\hline & $(0.096)$ & $(0.943)$ & $(0.157)$ & $(0.626)$ & $(0.460)$ & $(0.692)$ \\
\hline \multirow[t]{2}{*}{ Institution } & -0.037 & 0.359 & 0.035 & -0.083 & -0.793 & -0.171 \\
\hline & $(0.659)$ & $(0.492)$ & $(0.691)$ & $(0.561)$ & $(0.274)$ & $(0.251)$ \\
\hline \multirow[t]{2}{*}{ CRISIS_D } & -0.114 & - & - & 0.442 & - & - \\
\hline & $(0.501)$ & & & $(0.121)$ & & \\
\hline Bank-level characteristics & Yes & Yes & Yes & Yes & Yes & Yes \\
\hline Macroeconomic variables & Yes & Yes & Yes & Yes & Yes & Yes \\
\hline Country Dummy & Yes & Yes & Yes & Yes & Yes & Yes \\
\hline Year Dummy & No & Yes & Yes & No & Yes & Yes \\
\hline Number of Observations & 2267 & 809 & 1458 & 856 & 328 & 305 \\
\hline R-squared (Overall) & 0.4960 & 0.4642 & 0.3727 & 0.4120 & 0.4232 & 0.4253 \\
\hline
\end{tabular}

The panel data regressions estimate the relation between bank risk and regulation before the crisis (2005-2009) and after the crisis (2010-2018) periods. The sample includes 225 banks in 18 countries in the MENA region. Total sample of banks is split in two groups: Conventional banks and Islamic banks. Dependent variable is distance-to-default (or Z-score) as a measure of bank insolvency risk. Bank-level characteristics and other independent variables are computed as of year $t$. All the regressions control for year and country fixed effects. *,**, and *** indicate statistical significance at the 10,5 , and $1 \%$ level, respectively. The values in parenthesis represent ' $p$-value'. Bank-level characteristics, regulation, ownership, and macroeconomic variables are described in Appendix A

official supervisory power. Thus, our evidence suggests that the Basel III framework and the regulatory reform initiatives in the post-global financial crisis period seem to have reduced bank risk level in the MENA countries. This finding contradicts Haque (2018), who report that bank regulation and ownership effects are "either statistically insignificant or inconsistent, for both the pre- and postGFC periods" (Haque, 2018, p. 19). 
The effect of ownership structure on bank risk-taking seems to be different before and after the crisis. While ownership concentration and government ownership have a strong (positive) impact on the risk-taking behavior of CBs (that is, the increased level of concentration and government holding decreases a bank's credit risk) in the post-crisis period, this effect is insignificant in the sample of IBs. We may conclude that the financial decisions of IBs to pursue risky strategies to increase their return will depend on the expectations regarding the regulatory authority's behavior and not on the type of ownership structure. Furthermore, more powerful institutions in the post-crisis period seem to reduce the appetite for risk-taking of both CBs and IBs.

The results in Table 7 also display some differences in the effect of the regulatory measure on IBs and CBs' insolvency risk before and after the crisis. Again, the regulatory effects seem to play a significant role in shaping the risk-taking behavior of CBs in both the pre-crisis and post-crisis periods, whereas this effect is absent in the post-crisis period for the sample of IBs. One possible reason could be the fact that IBs are more durable than their conventional counterparts, which is due to the strong capital ratios that are considerably higher than those of the traditional banks (Abedifar et al. 2013; Louati et al. 2015). Finally, the level of institutional quality does not impact on the risk-taking behavior of both types of banking systems in the MENA region.

These results provide new evidence on the increased role of regulations (e.g., supervisory power and private monitoring) and ownership (e.g., the concentration of shareholding) in shaping the risk-taking behavior of banks in the post-crisis period (specifically, the credit risk level of CBs). While ownership structure has no role to play, the improvement in the institutional environment in the post-crisis period has a positive impact on the risk-taking behavior of IBs, which could be explained by the fact that IBs operate under the Shariah principles. The policy implications of our findings are that decision-makers and regulators in the MENA region should carefully tailor banking reform initiatives related to capital stringency, banking supervision and activity restriction in the post-crisis period depending on the expected effect on Islamic and conventional banking institutions.

\section{Robustness checks}

We test the robustness of our results in several ways. First, in addition to the fixed and random effect models reported in Tables 3 and 4, the analysis employs identical specifications using the Generalized Method of Moments (GMM) estimator, developed by Arellano and Bond (1995). This estimator controls for the presence of unobserved firm-specific effects and the endogeneity of explanatory variables. The instruments used depend on the assumption made as to whether the variables are endogenous or predetermined, or exogenous. In this approach, the validity of the instruments is tested using a Sargan test of over-identifying restrictions and a test of the absence of serial correlation of the residuals. The AR(2) test detects the secondorder autocorrelation in first differences. We treat the lagged dependent variables as 
endogenous so that GMM-style instruments of deeper lags are created. ${ }^{11}$ The outcomes of the GMM tests for regulation and ownership effects for the whole sample are reported in Table 8 . We run the regressions including both the regulatory and ownership measures as stand-alone variables and the interaction term between the regulatory variables and each measure of ownership structure. The results support our previous findings that the effect of regulatory measures is reinforced for banks with high level of ownership concentration or foreign shareholding.

Second, we investigate the robustness of our results using alternative specifications and different control variables. For example, we proxy bank insolvency risk with volatility in equity return $(\mathrm{EV})$ in addition to distance to default and portfolio risk. We use non-performing loans to gross loans (NPL/GL) as an alternative measure of bank credit risk. The results are similar to those reported in Table 3 (with $Z$-score measure) and confirm the moderating role of ownership structure (e.g., ownership concentration and government shareholding) on the relationship between regulatory measures and bank risk. Next, we repeat our analysis emphasizing the interaction effect of bank regulation and different measures of ownership structure (see Appendix B, Table 10). In Model 1, we run the regressions without an interaction term, whereas in the next three models, we estimate the interaction effect of each regulatory measure with the three ownership indicators. In Table 11, we drop the crisis dummy and use year dummies instead. Again, the results are quite similar. Since our preliminary analysis indicates that the GCC dummy variable is significant, we split the sample into two sub-samples, including GCC and non-GCC countries, respectively. Our results align with Maghyereh and Awartani (2014), who find no significant relationship between regulatory capital requirements and the likelihood of bank distress in the GCC region. However, official supervisory power and activity restrictions do exert a negative effect on bank distress.

\section{Conclusions}

In this paper, we investigate the effect of regulation and ownership on banks' risktaking behavior in emerging economies (specifically, the MENA countries). The existing empirical literature claims that regulation may affect banks' risk-taking behavior, but risky strategies of these banks, in turn, may induce the policy makers to impose stricter regulatory requirements. The public and private views of bank regulation are used to explain the relationship between regulatory measures and bank risk. Also, we are the first to investigate whether the regulatory and ownership effects are significantly different between Islamic and conventional banking in the MENA region.

\footnotetext{
11 More specifically, we use the Arellano-Bover/Blundell-Bond panel data estimator-a test for serial correlation in the first-differenced errors. The moment conditions are valid only if there is no serial correlation in the idiosyncratic errors. We reject the null hypothesis of no serial correlation in the first-differenced errors but accept the null hypothesis of no serial correlation in the second-differenced errors which implies that moments conditions are valid.
} 


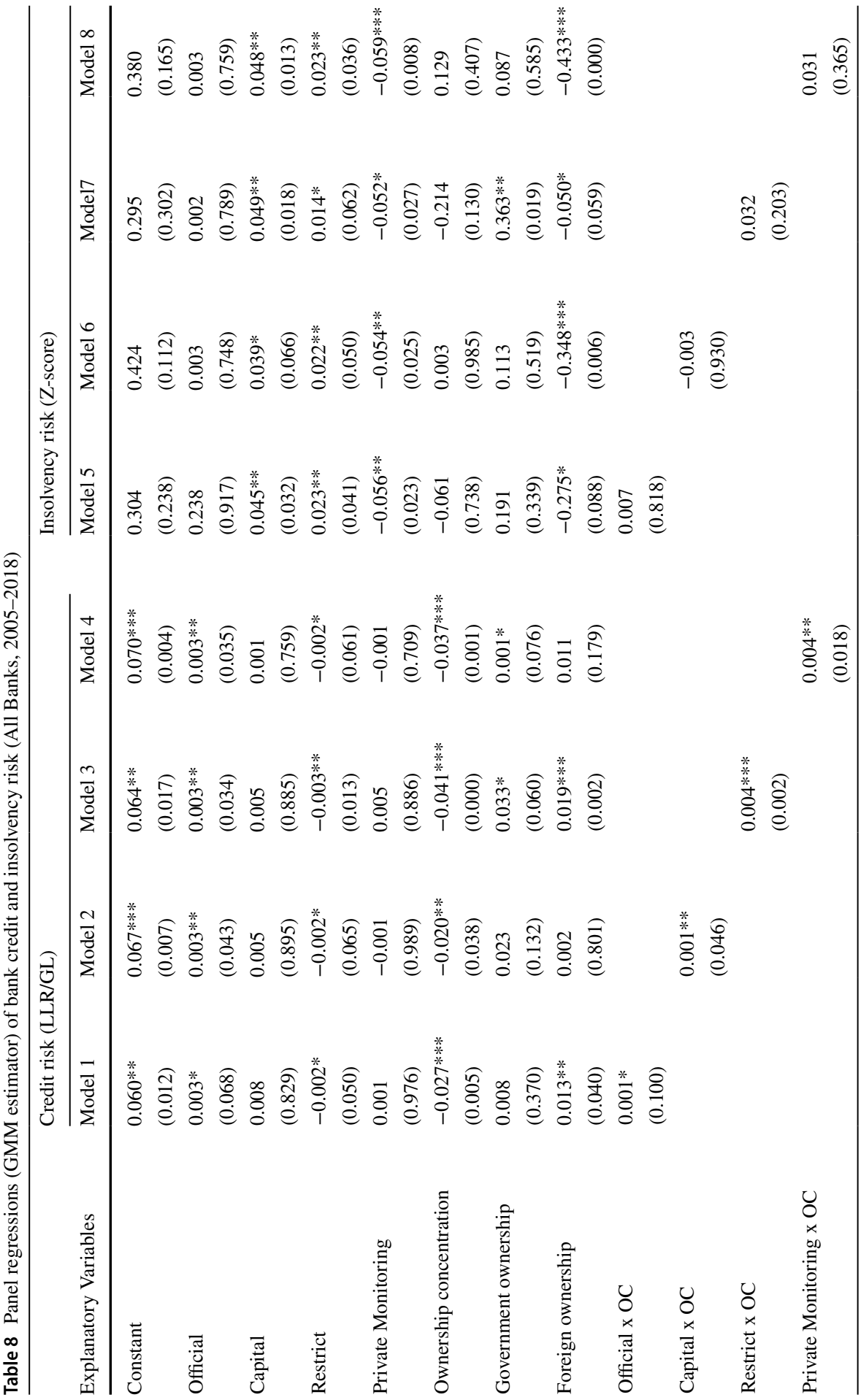




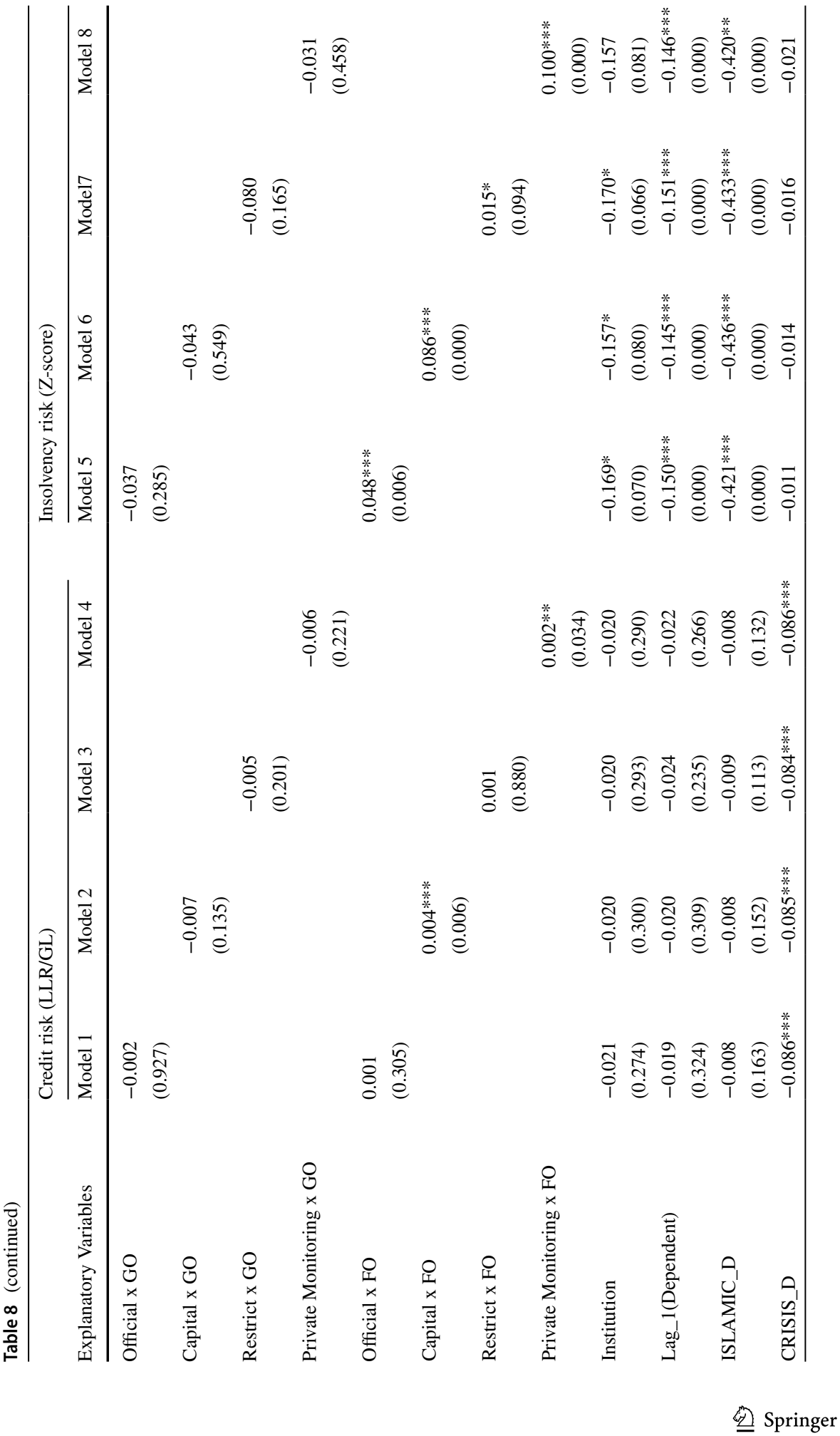




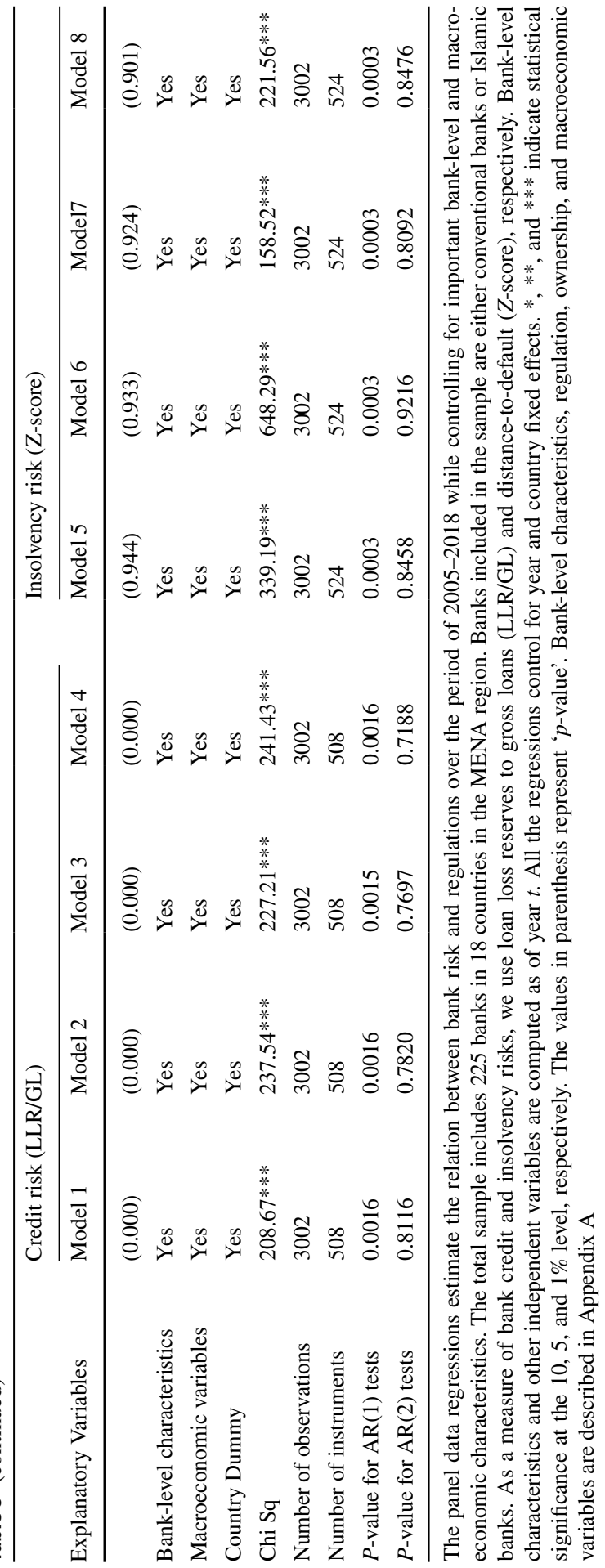


In line with the 'private interest' view of bank regulation, we find that official supervisor power increases the level of bank credit risk; however, private monitoring does have the opposite effect. We provide further support of the 'private interest view' when considering the effect of private monitoring on bank insolvency risk. In addition to regulations, ownership structure (e.g., ownership concentration and foreign ownership) also plays a significant role in explaining banks' risk-taking behavior in the MENA region. Our results add value to the existing empirical literature as they confirm the significant role of regulation and ownership in shaping banks' risk behavior. The findings indicate that stringent regulations (e.g., private monitoring and activity restrictions) combined with improved supervisory power may force banks to reduce their risk level.

Next, our analysis reveals that the effect of bank regulation on risk-taking behavior strongly depends on the type of ownership structure of a bank. Specifically, government banks and those with strong foreign presence will follow different risky strategies in the face of increased regulatory pressure. In line with Haque (2018), we find that the effect of regulatory measures is more pronounced for banks with a higher level of ownership concentration.

Our study is the first to suggest that there is a strong differential effect of regulation and ownership on the risk-taking behavior of Islamic banking institutions. First, the evidence shows a significantly positive (negative) influence of the official supervisory index (private monitoring) on the credit risk level of CBs, while this effect is the opposite for IBs. Moreover, the activity restriction index seems to play a significant role in shaping the risk-taking behavior of IBs only. Second, we find an insignificant ownership effect in the sample of IBs, which can be taken as a sign that the effect of regulatory reforms does not depend on the type of ownership structure of Islamic banks but rather on regulatory authority's behavior. Third, the moderating effect of ownership is also significantly different between the two banking systems. For example, in the sample of CBs, the ownership structures that moderate the relationship between regulatory measures and credit risk is government shareholding and ownership concentration. However, in the sample of IBs, the interaction effect with ownership measures is insignificant. The analysis of bank insolvency risk indicates that IBs with high level of foreign ownership is enforced to increase their risk level in the face of increased regulation pressure (e.g., enhanced restrictions on bank activities). This finding supports Naceur and Omran (2011), who advocate fewer activity restrictions on banks in the MENA region to stimulate market competitiveness and increase banking system stability.

Our results have important implications for regulators, policy makers, and bank managers. First, we find that the effect of stringent bank regulation on banks' risktaking behavior in the MENA region is moderated by ownership structure only in the group of CBs. For IBs, the regulatory reforms and the quality of institutions in the home country are important drivers of their risk behavior. The policy implications of these findings are that regulators in the MENA region should not push to privatize government-owned banks and that the reduction of the entry barriers to foreign banks is likely to restrict the excessive risk-taking of banks. In addition, decision-makers should carefully tailor banking reform initiatives related to monitoring and banking supervision depending on the type of the banking system 
(Islamic vs. conventional) as they may have different risk management strategies. Since ownership structure itself has no role to play in shaping the risk-taking behavior of IBs, regulatory pressure remains the main instrument for control over their choice of risky strategies. Based on these findings, we recommend that regulatory institutions in the MENA countries are more proactive in enforcing capital stringency provisions in line with the Basel III regulatory framework in order to enhance banking sector stability during the COVID-19 pandemic.

Finally, bank managers should take appropriate steps to reduce the impact of downside risk from depletion of capital buffers, which is expected to be significant during the pandemic. A future extension of this study will focus on testing the effect of the COVID-19 pandemic on bank risk and performance in the MENA countries. The findings of this paper also provide compelling insights to the policy makers and regulators in other countries and regions where Islamic and conventional banks coexist, in setting appropriate policies that enforce capital provisions and market-based disclosures, in order to restrict banks' risk-taking behavior and enhance banking sector stability.

\section{Appendix}

See Table 9.

\section{Appendix B}

See Tables 10 and 11. 


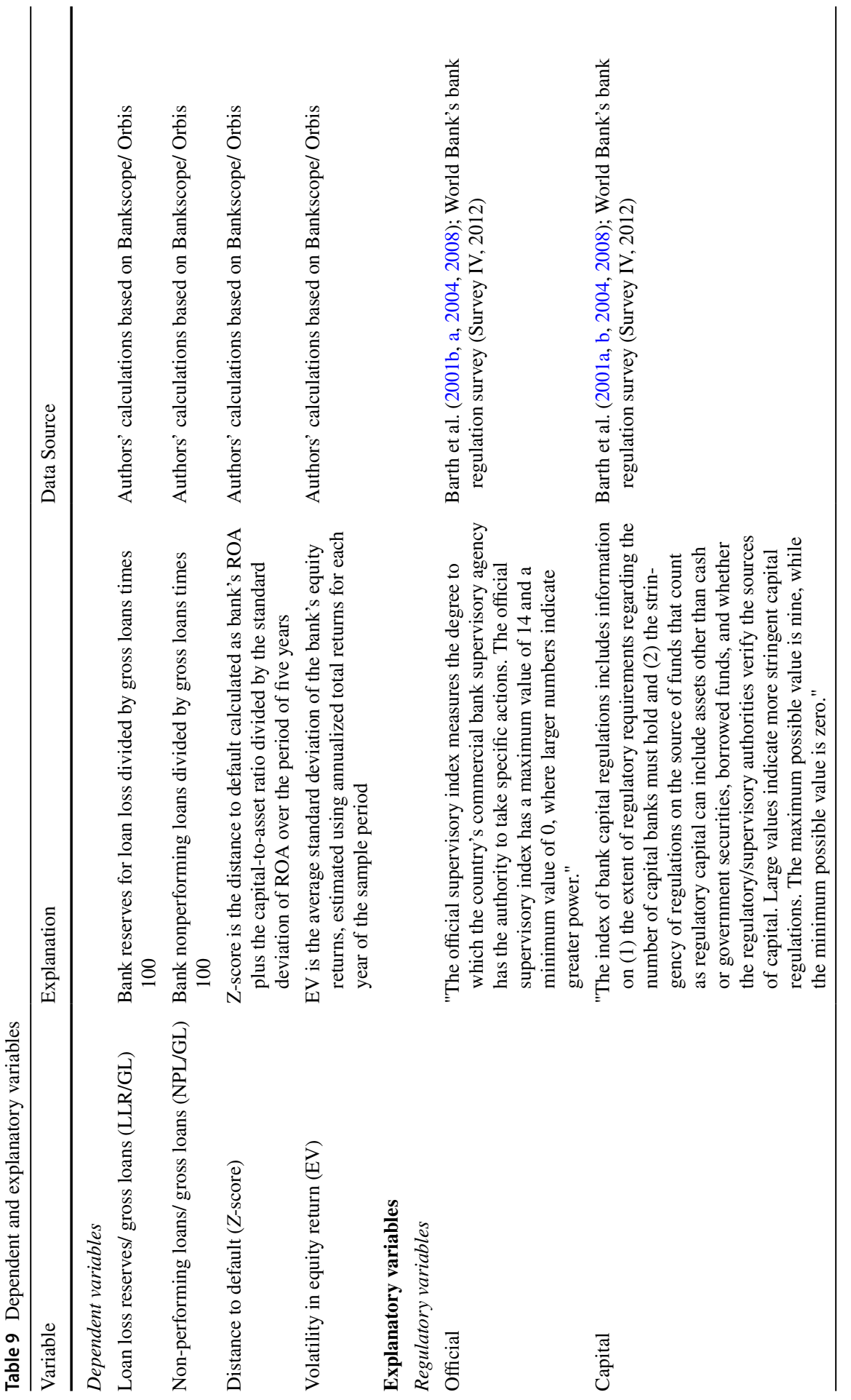




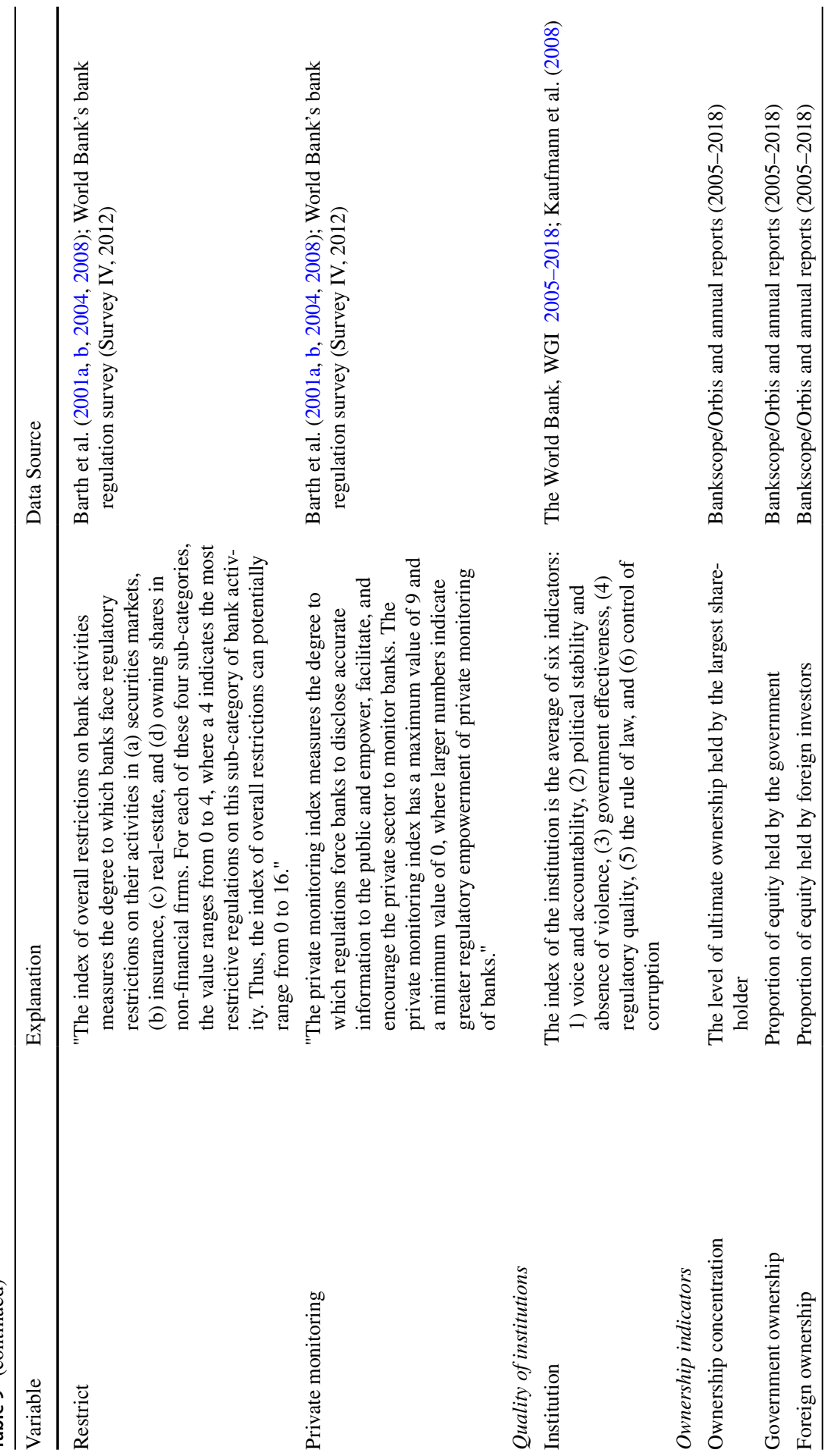




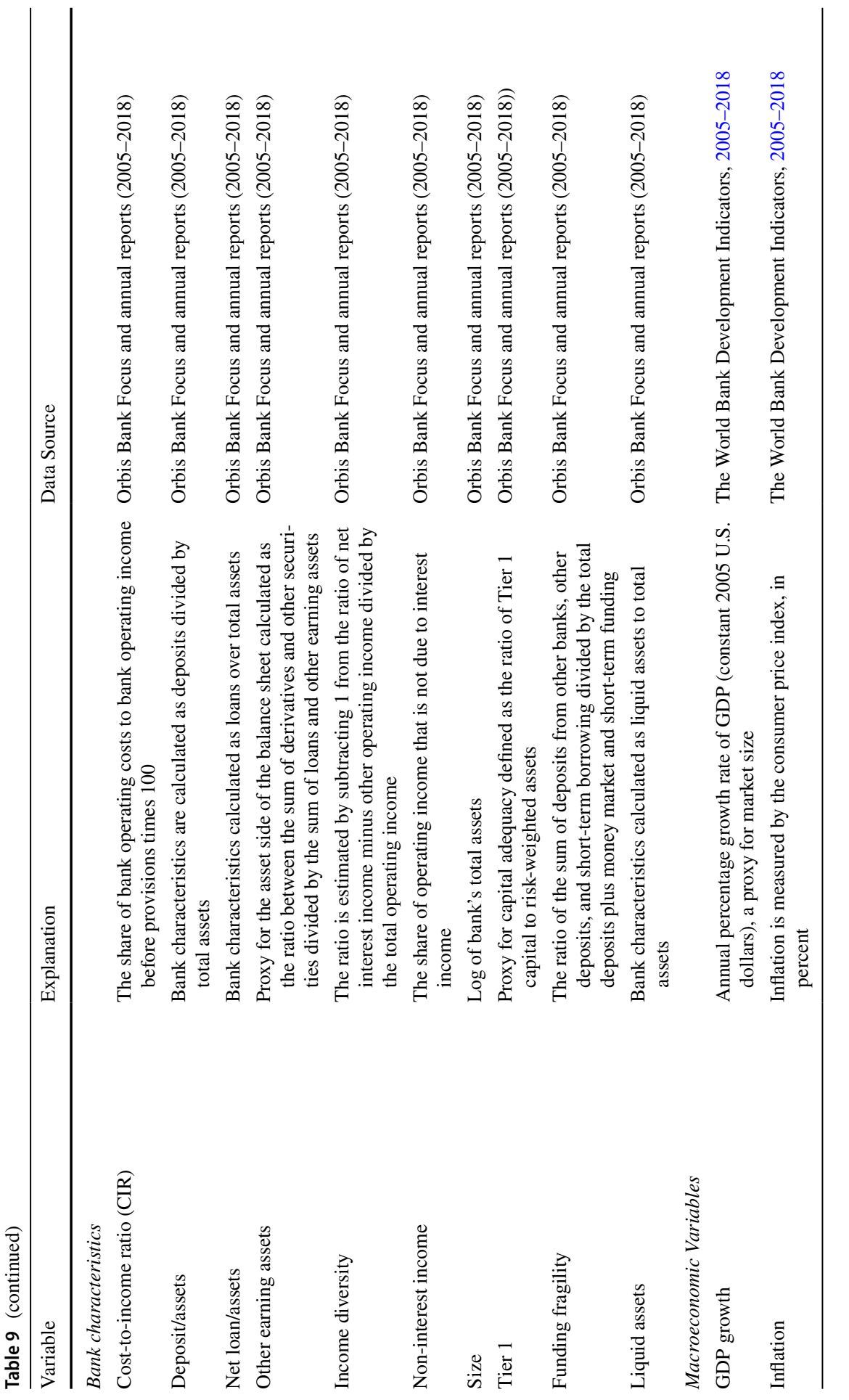




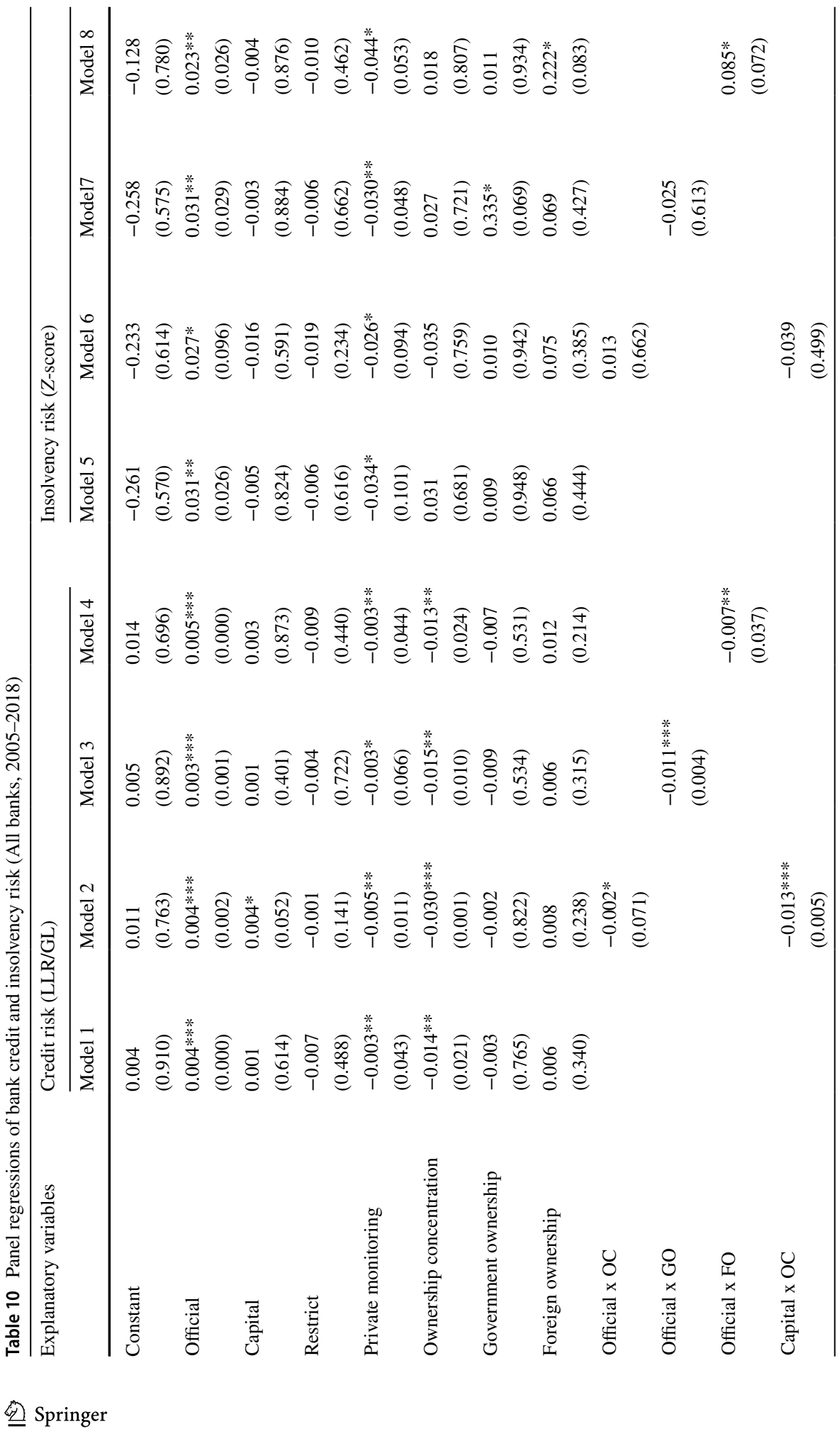




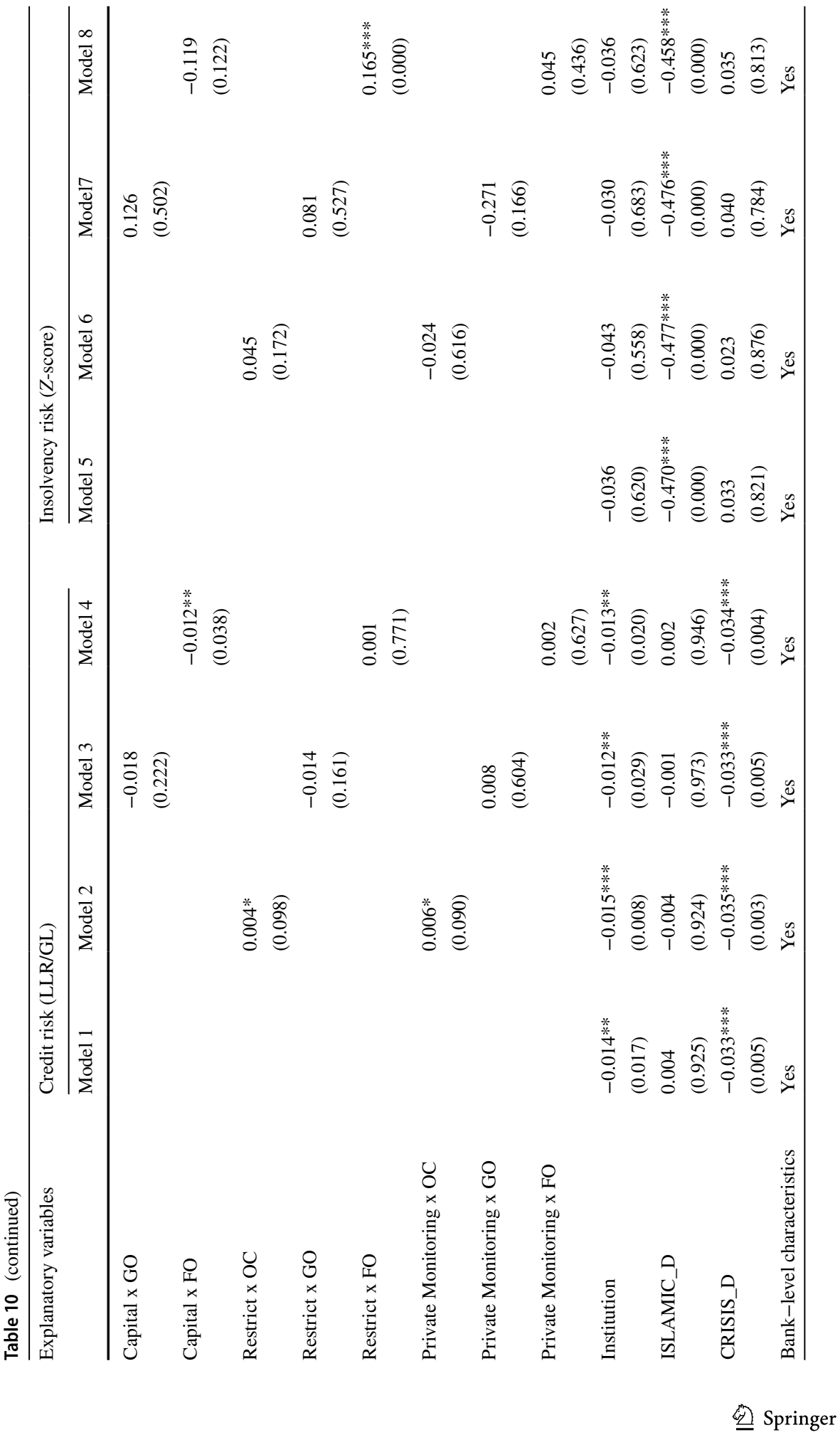




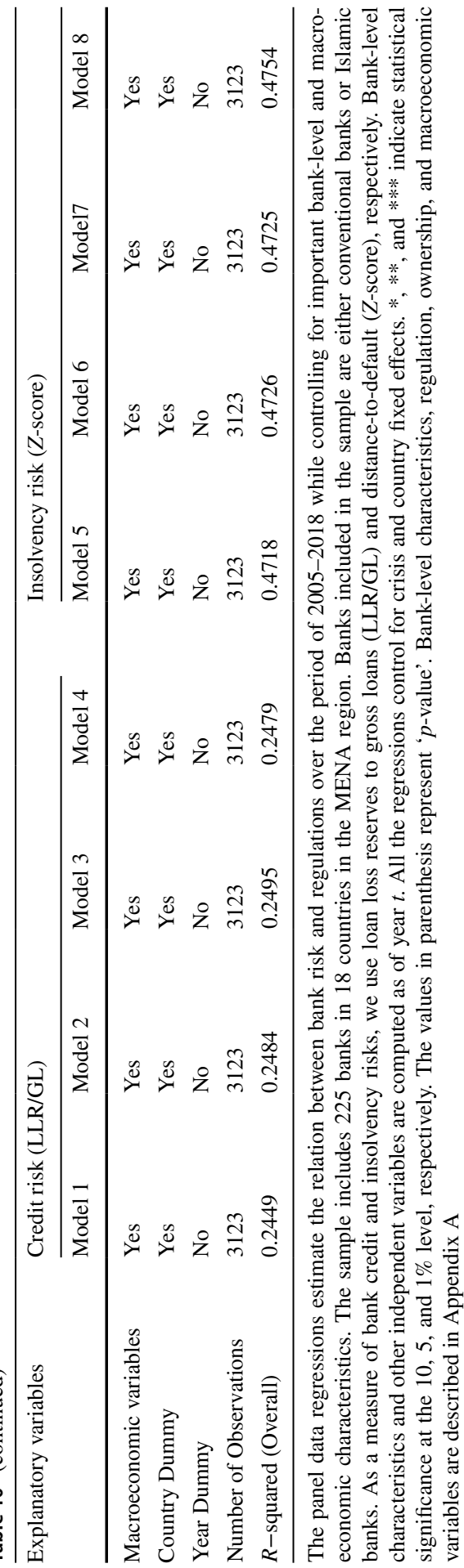




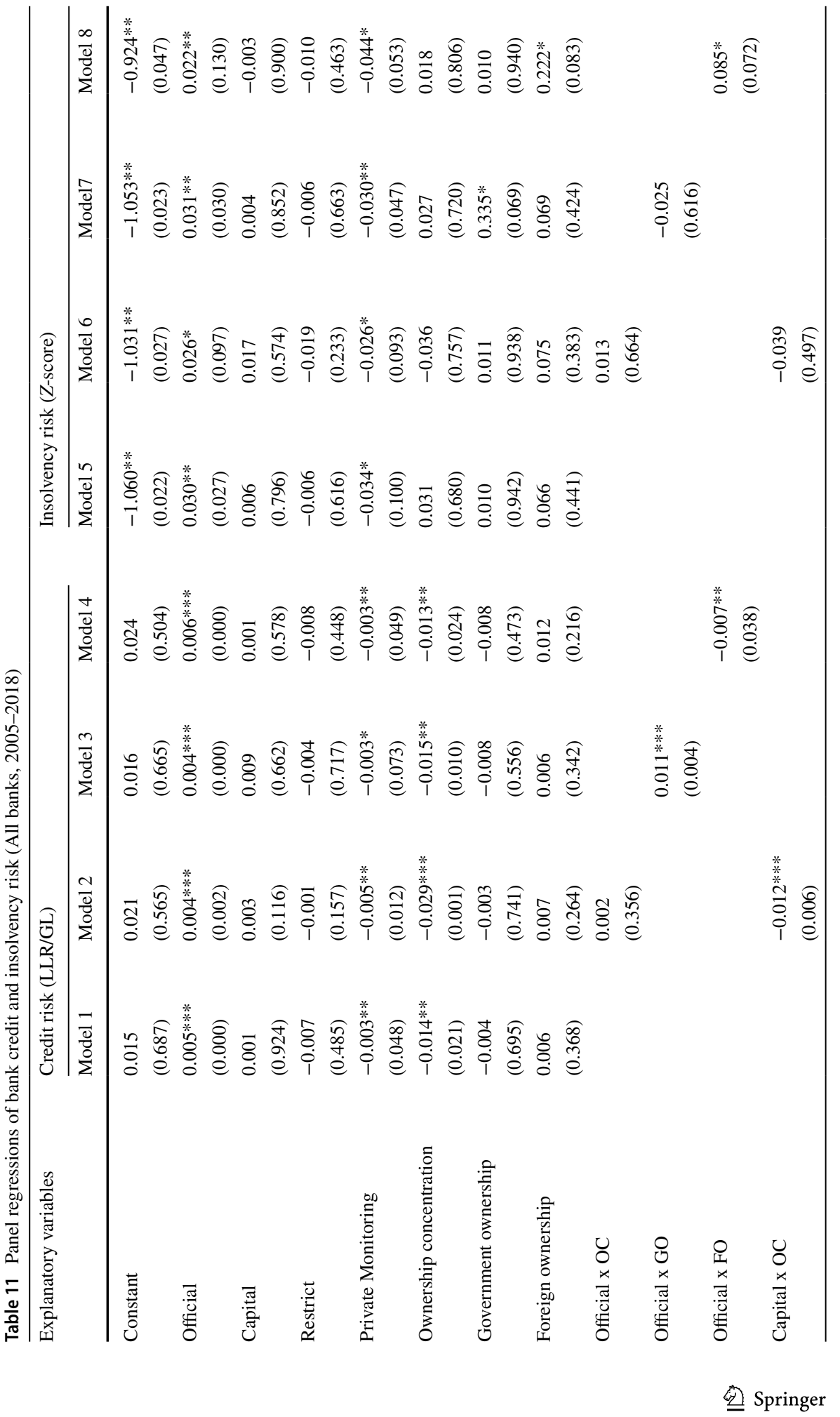




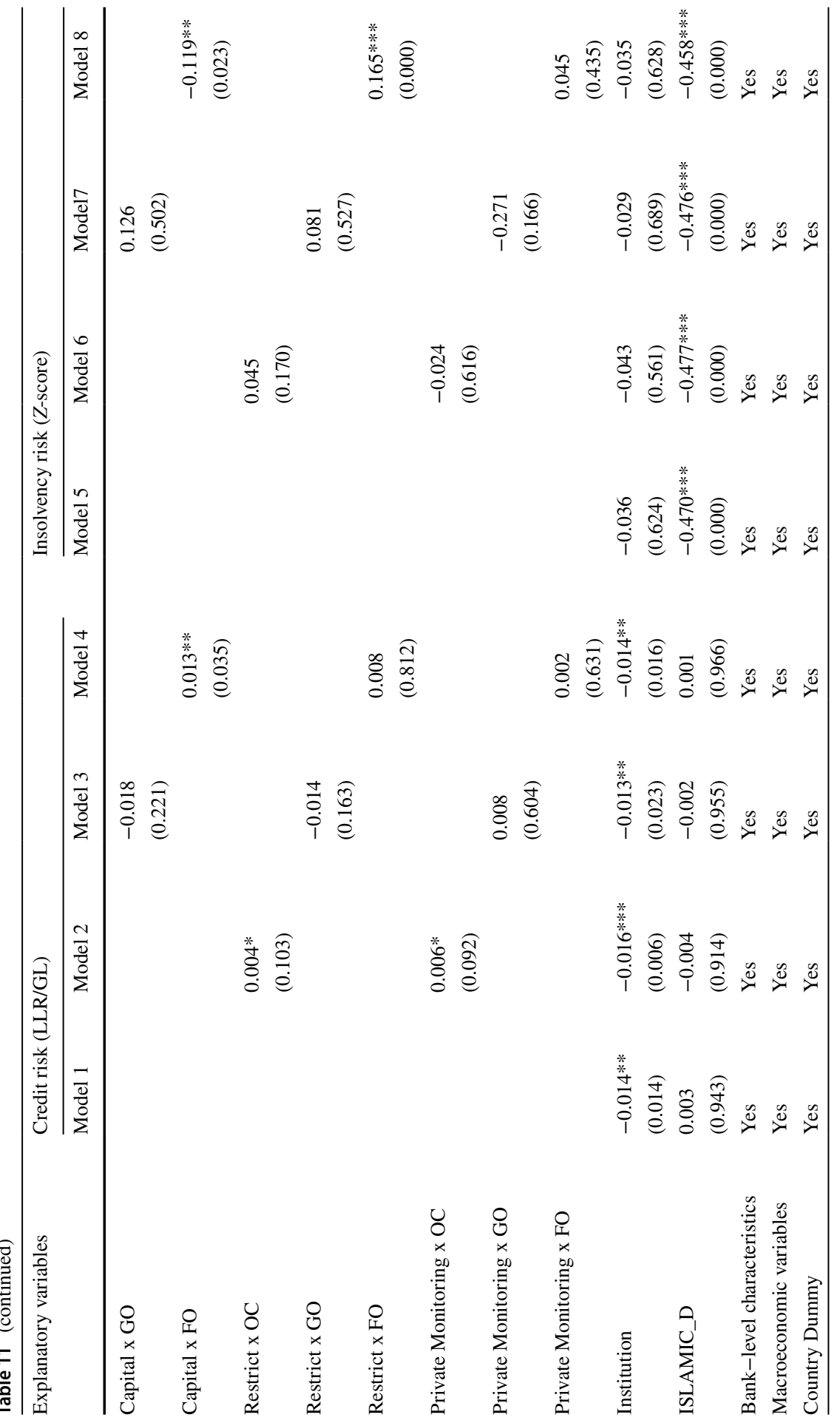




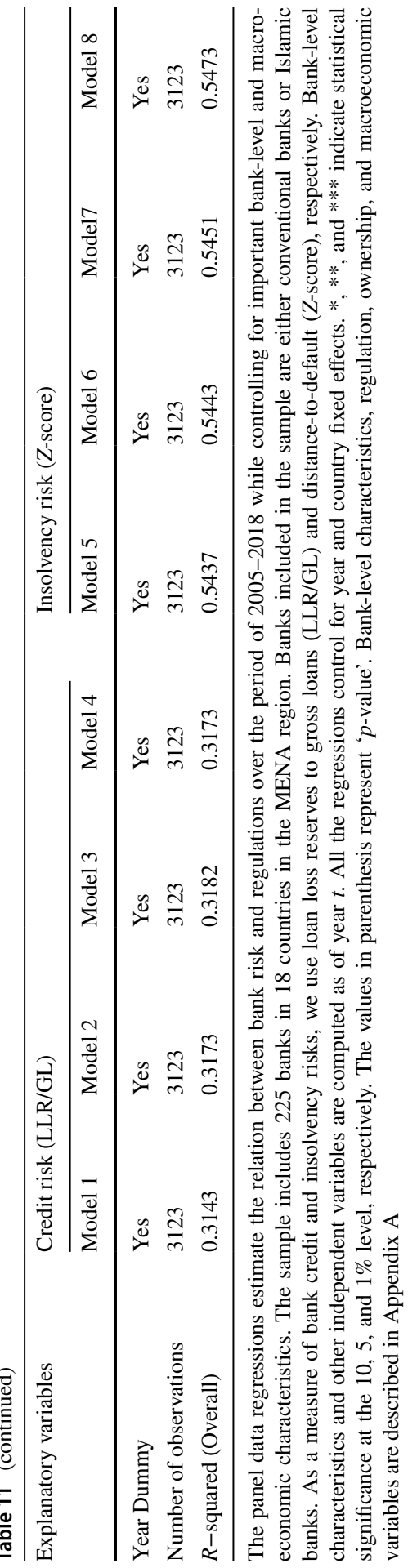


Supplementary Information The online version contains supplementary material available at https://doi. org/10.1007/s11846-022-00529-5.

\section{References}

Abedifar P, Tarazi A, Molyneux P (2013) Risk in Islamic banking. Review of Finance 17:2035-2096

Agoraki MK, Delis MD, Pasiouras F (2011) Regulation, competition, and bank risk-taking in transition countries. J Financ Stab 7:38-48

Alsharif M, Md Nassir A, Kamarudin F, Zariyawati MA (2016) Basel III: Main issues for GCC Banks. Int J Econ Commerce Manage 4(11):541-563

Altunbas Y, Carbo S, Gardner E, Molyneux P (2007) Examining the relationship between capital, risk and efficiency in European banking. Eur Financ Manag 13(1):49-70

Andres PD, Vallelado E (2008) Corporate governance in banking: the role of the board of directors. J Bank Finance 32(12):2570-2580

Anginer D, Demirgüç-Kunt A (2014) Bank capital and systemic stability. Policy Research Working Paper No. 6948, Washington, DC: The World Bank, Available at: https://ideas.repec.org/p/wbk/wbrwps/ 6948.html

Arellano M, Bond O (1995) Another look at the instrumental variable estimation of error-componentsmodels. J Economet 68(1):29-51

Ayadi R, De Groen WP (2013) Banking and insurance in the GCC countries: Is there regulatory convergence with the EU? Sharaka Research Paper No. 4, CEPS (July 2013). Available at: http://www. ceps.eu/book/banking-and-insurance-gcc-countries-there-regulatory-convergence-eu

Barry TA, Lepetit L, Tarazi A (2011) Ownership structure and risk in publicly held and privately owned banks. J Bank Finance 35(5):1327-1340

Barth JR, Caprio G Jr, Levine R (2001a) The regulation and supervision of bank around the world: a new database. In: Litan RE, Herring R (eds) Brookings-Wharton Paper on Financial Services. Brookings Institution Press, Washington DC, pp 183-240

Barth JR, Caprio G Jr, Levine R (2001b) Rethinking Bank Regulation: Till Angels Govern. Cambridge University Press, New York

Barth JR, Caprio G Jr, Levine R (2004) Bank regulation and supervision: What works best? J Financial Intermediation 13(2):205-248

Barth JR, Lin C, Ma Y, Seade J, Song FM (2013) Do bank regulation, supervision and monitoring enhance or impede bank efficiency? J Bank Finance 37(8):2879-2892

Barth JR, Caprio Jr G, Levine R (2008) Bank regulations are changing: For better or worse? World Bank Policy Research Working Paper, No. 4646, Washington, DC: The World Bank. Available at https:// papers.ssrn.com/sol3/papers.cfm?Abstract_id=1149579\#

Bashir A, Hassan A (2017) Interrelationship among Basel capital regulation, risk, and efficiency in Pakistani commercial banks. Bus Econ Rev 9(2):165-186

Beck T, Demirguc-Kunt A, Levine R (2006) Bank concentration, competition, and crisis: first results. J Bank Finance 30(5):1581-1603

Beck T, Demirgüç-Kunt A, Merrouche O (2013) Islamic vs. conventional banking: Business model, efficiency and stability. J Bank Finance 37(2):433-447.

Beltratti A, Stulz RM (2012) The credit crisis around the globe: Why did some banks perform better? J Financ Econ 105(1):1-17

Ben Khediri K, Charfeddine L, Ben Youssef S (2015) Islamic versus conventional banks in the GCC countries: a comparative study using classification techniques. Res Int Bus Finance 33(C):75-98.

Bitar M, Saad W, Benlemlih M (2016) Bank risk and performance in the MENA region: the importance of capital requirements. Econ Syst 40(3):398-421

Bourgain A, Pieretti P, Zanaj S (2012) Financial openness, disclosure and bank risk-taking in MENA countries. Emerg Mark Rev 13(3):283-300

Bourkis K, Nabi MS (2013) Islamic and conventional banks' soundness during the 2007-2008 financial crisis. Rev Financial Econ 22(2):68-77

Boyd JH, De Nicolò G, Jalal AM (2006) Bank risk-taking and competition revisited: new theory and new evidence. IMF Working Paper No. 06/297, Washington DC: international Monetary Fund. Available at: https://www.imf.org/external/pubs/ft/wp/2006/wp06297.pdf. 
Chen S-H, Hwang T-C, Liu H-H (2012) Motivation of risk-taking behavior of banks in different countries: an international perspective. Banks Bank Syst 7(2):116-128

Danisman GO, Demirel P (2019) Bank risk-taking in developed countries: The influence of market power and bank regulations. J Int Financial Markets Institutions Money 59 (C):202-217.

Demirgüc-Kunt A, Huizinga H (2010) Bank activity and funding strategies: the impact on risk and return. J Financ Econ 98(3):626-650

Djankov S, La Porta R, Lopez-De-Silanes F, Shleifer A (2002) The regulation of entry. Quart J Econ 117(1):1-37

Farazi S, Feyen E, Rocha R (2011) Bank ownership and performance in the Middle East and North Africa Region. Rev Middle East Econ Finance 9(2):159-196

Forssbæck J (2011) Ownership structure, market discipline, and banks' risk-taking incentives under deposit insurance. J Bank Finance 35(10):2666-2678

Ghosh S (2017) Corporate governance reforms and bank performance: evidence from the Middle East and North Africa. Corporate Governance Int J Bus Soc 17(5):822-844

González LO, Razia A, Búa MV, Sestayo RL (2017) Competition, concentration and risk- taking in Banking sector of MENA countries. Res Int Bus Finance 42(C):591-604.

Grassa R (2012) Islamic banks' income structure and risk: evidence from GCC countries. Account Res J 25(3):227-241

Hammami Y, Boubaker A (2015) Ownership structure and bank risk-taking: empirical evidence from the Middle East and North Africa. Int Bus Res 8(5):271-284

Haque F (2018) Ownership, regulation, and bank risk-taking: evidence from the Middle East and North Africa (MENA) region. Corp Gov 19(1):23-43

Haque F, Brown K (2017) Bank ownership, regulation, and efficiency: Perspectives from the Middle East and North Africa (MENA) region. Int Rev Econ Finance 47(C):273-293.

Haw I-M, Ho S, Hu B, Wu D (2010) Concentrated control, institutions, and banking sector: an international study. J Bank Finance 34(3):485-497

Iannotta G, Nocera G, Sironi A (2007) Ownership structure, risk and performance in the European banking industry. J Bank Finance 31(7):2127-2149

Kaufmann D, Kraay A, Mastruzzi M (2008) Governance matters VII: Aggregate and individual governance indicators, 1996-2007, World Bank Policy Research Working Paper No. 4978, Washington, DC: The World Bank.

Kobeissi N, Sun X (2010) Ownership structure and bank performance: evidence from the Middle East and North Africa region. Comp Econ Stud 52(3):287-323

Laeven L, Levine R (2009) Bank governance, regulation and risk taking. J Financ Econ 93(2):259-275

Lassoued N, Sassi H, Attia MBR (2016) The impact of state and foreign ownership on banking risk: Evidence from the MENA countries. Res Int Bus Finance 36(C):167-178.

Lee C, Hsieh M (2013) The impact of capital on profitability and risk in Asian banking. J Int Money Financ 32(2):251-281

Lensink R, Meesters A, Naaborg I (2008) Bank efficiency and foreign ownership: Do good institutions matter? J Bank Finance 32(5):834-844

Lepetit L, Nys E, Rous P, Tarazi A (2008) Bank income structure and risk: an empirical analysis of European banks. J Bank Finance 32(8):1452-1467

Li X, Feng H, Zhao S, Carter DA (2021) The effect of revenue diversification on bank profitability and risk during the COVID-19 pandemic. Finance Res Lett [101957].

Louati S, Abida IG, Boujelbene Y (2015) Capital adequacy implications on Islamic and non-Islamic bank's behavior: Does market power matter? Borsa Istanbul Rev 15(3):192-204

Maghyereh AI, Awartani B (2014) Bank distress prediction: Empirical evidence from the Gulf Cooperation Council countries. Res Int Bus Finance 30(C): 26-147.

Mateev M, Bachvarov P (2021) Regulation, ownership, and bank performance in the MENA region: evidence from Islamic and conventional banks. Emerg Markets Rev 47(2):100789.

Mateev M, Bachvarov P (2018) Bank behavior in good times and bad times: the impact of regulations and risk taking on bank performance. Am J Finance Account 5(3):193-252

Micco A, Panizza U, Yaez M (2007) Bank ownership and performance: does politics matter? J Bank Finance 31(1):219-241

Mohseni-Cheraghlou A (2012) Bank regulation and supervision in the Arab world. Available at: http:// menablog.worldbank.org/banking-regulation-and-supervision-arabworld.

Mondher K, Lamia M (2016) Bank governance, regulation and risk taking: evidence from Tunisia. Int Finance Bank 3(2):122-137 
Moudud-Ul-Huq S (2020) Does bank competition matter for performance and risk-taking? Empirical evidence from BRICS countries. Int J Emerg Mark 16(3):409-447

Naceur SB, Omran M (2011) The effect of bank regulations, competition, and financial reforms on banks' performance. Emerg Mark Rev 12(1):1-20

Ng Jeffrey, Roychowdhury S (2013) Loan loss reserves, regulatory capital, and bank failures: evidence from the 2008-2009 economic Crisis. Review of Accounting Studies (RAST) Conference, 8-9 November 2013.

Olson D, Zoubi T (2017) Convergence in bank performance for commercial and Islamic banks during and after the global financial crisis. Quart Rev Econ Finance 65(C):71-87.

Otchere I (2005) Do privatized banks in middle- and low-income countries perform better than rival banks? An intra-industry analysis of bank privatization. J Bank Finance 29(8-9):2067-2093

Pasiouras F, Tanna S, Zopounidis C (2009) The impact of banking regulation on banks' cost and profit efficiency: Cross-country evidence. Int Rev Financ Anal 18(5):294-302

Prasad A, Monem HA, Martinez PG (2016) Macroprudential Policy and Financial Stability in the Arab Region. IMF Working Paper No WP/16/98, Washington DC: International Monetary Fund.

Sarker N, Nahar S (2017) The impact of ownership structure on bank credit risk: evidence from Bangladesh. Eurasian J Bus Econ 10(19):19-36

Schaeck K, Cihák M (2007) Banking competition and capital ratios, IMF Working Paper WP/07/216, Washington D.C.: International Monetary Fund, D.C. Available at: https://www.imf.org/external/ pubs/ft/wp/2007/wp07216.pdf.

Shehzad CT, De Haan J, Scholtens B (2010) The impact of ownership concentration on impaired loans and capital adequacy. J Bank Finance 34(2):399-408

Shleifer A, Vishny RW (1997) A survey of corporate governance. J Finance 52(2):737-783

Srairi S (2013) Ownership structure and risk-taking behavior in conventional and Islamic banks: evidence for MENA countries. Borsa Istanbul Rev 13(4):115-127

The World Bank Development Indicators, 2005-2018. World Development Indicators [Online]. Available at: http://data.worldbank.org/indicator/NY.GDP.MKTP.CD (Accessed 15/07/2019).

The World Bank Worldwide Governance Indicators, 2005-2018. Interactive Data Access [Online]. Available at: http://info.worldbank.org/governance/wgi/index.aspx\#reports (Accessed 15/07/2019).

Publisher's Note Springer Nature remains neutral with regard to jurisdictional claims in published maps and institutional affiliations. 